\title{
COMMENT
}

\section{BLACK RAGE AND THE CRIMINAL LAW: A PRINCIPLED APPROACH TO A POLARIZED DEBATE}

\author{
JUDD F. SNEIRSON†
}

\section{INTRODUCTION}

Tragedy struck the Long Island Railroad on December 7, 1993, as the 5:33 to Hicksville left the New York City limits. ${ }^{1}$ Methodically, as if collecting train tickets, Colin Ferguson passed down the aisle of the third car of the train, steadily shooting to his right and then to his left, until he emptied two fifteen-bullet clips into twenty-five defenseless Long Island commuters. ${ }^{2}$ Handwritten notes in Ferguson's pockets explained his actions as a venting of the rage he-a black man-felt toward "everyone from Gov[ernor] Mario M. Cuomo to the state Workers' Compensation Board to Asians, whites, and 'Uncle Tom Negroes."'3 Months later, the racial stress, anxiety, and anger evidenced in these notes would provide the foundation for Ferguson's legal defense: a new twist on the traditional insanity defense called the "black rage" defense."

† B.A. 1992, Williams College; J.D. Candidate 1996, University of Pennsylvania. I would like to thank Risa Cherry, Scott Goldberg, Katherine Kelly, Marc Kesselman, Kimberly Kessler, Craig Lehner, Michael Manasse, and Michael Raibman for their thoughtful suggestions on earlier drafts; my Law Review colleagues for their careful editing; and Elisa Duncan and my parents for their love and support.

I dedicate this Comment to the memory of Al Bennett, whose English lessons and life lessons inspire well after high school.

${ }^{1}$ See James Barron, Portrait of Suspect Emerges in Shooting on L.I. Train: Notes Found on Man Speak of His Hatred, N.Y. TIMES, Dec. 9, 1993, at A1, B8 (detailing the situation on the Hicksville train).

${ }^{2}$ See Francis X. Clines, Gunman in a Train Passes Out Death, N.Y. TIMES, Dec. 9, 1993, at A1. Six died and nineteen were wounded in the shooting spree. See Rorie Sherman, 'Black Rage' Rises Again as Defense, NAT'L L.J., Apr. 25, 1994, at A6 (describing the aftermath of Ferguson's rampage); see also Peter Marks, 5 Everyday People, by Chance or Ritual, Riding in Car No. 3, N.Y. TIMES, Dec. 9, 1993, at A1, B9 (describing the victims of the shooting spree).

${ }^{3}$ Barron, supra note 1, at A1; see also Excerpts from Papers and Letter of Suspect, N.Y. TIMES, Dec. 9, 1993, at B8 [hereinafter Papers and Letter of Suspect] (excerpting some of Ferguson's personal papers); Charisse Jones, In Notes and Past of Accused, Portrait of Boiling Resentment, N.Y. TIMES, Dec. 9, 1993, at B8 (detailing Ferguson's hatred of whites).

+See, e.g., Michael Alexander, Black Rage, NEwSDAY (N.Y.), May 9, 1994, at B4 
According to Ferguson's former defense attorneys, ${ }^{5}$ American society's pervasive and destructive racism gradually kindled and fueled a smoldering rage that operated as a catalyst to push their already mentally unstable client over the edge into insanity. ${ }^{6}$ This seemingly novel argument is not without legal or psychiatric precedent. In 1846, a New York appellate court embraced a similar argument, finding a man insane as a result of the brutality he suffered as a black man in upstate New York. ${ }^{7}$ The seminal sociological and psychiatric study Black Rage also propounds this argument, devoting an entire chapter to mental conditions arising from the constant racial stress many black Americans experience. ${ }^{8}$ Drawing upon these and other sources, Ferguson's attorneys

(discussing black rage and the black rage defense). The term "black rage" originates from the sociological and psychological study that first depicted the condition. See generally WILLIAM H. GRIER \& PRICE M. COBBS, BLACK RAGE (1968) (providing the first examination of black rage).

${ }^{5}$ Criminal defense attorneys William M. Kunstler and Ronald L. Kuby represented Ferguson at the height of the case's publicity. See John T. McQuiston, L.I.R.R. Trial Has Adviser 'Disgusted', N.Y. TIMES, Jan. 31, 1995, at B5. Convinced that he was not insane and did not perpetrate any crime, Ferguson resisted the planned black rage insanity defense, fired Kunstler and Kuby, and represented himself. See Telephone Interview with Ronald L. Kuby, Kunstler \& Kuby (Apr. 4, 1995) [hereinafter Kuby Telephone Interview].

On February 17, 1995, after 10 hours of deliberation, a jury rejected Ferguson's mistaken identity defense and found him guilty of murder and of attempted murder. See John T. McQuiston, Colin Ferguson Convicted of L.I.R.R. Train Massacre: Smiles in Courtroom as Verdict Is Read on the 93 Charges, N.Y. TIMES, Feb. 18, 1995, at A1. On March 22, 1995, a judge sentenced Ferguson to 200 years in prison. See John T. McQuiston, Rail Gunman to Spend Life Behind Bars, N.Y. TIMES, Mar. 23, 1995, at B1 (noting that Ferguson received the maximum sentence). Ferguson plans to appeal. See id.

"See Attorney and Congressman Debate "Black Rage" Defense (CNN television broadcast, Mar. 15, 1994), available in LEXIS, Nexis Library, Curnws File (interviewing William Kunstler) [hereinafter $C N N$ News]; see also Alexander, supra note 4, at B4 (stating that Ferguson's former attorneys wanted to "persuade a jury that Ferguson acted out of extreme racial stress ... when he killed six people and wounded 19 others"); Sherman, supra note 2, at A6 (paraphrasing Kunstler as stating that "American society's pervasive and destructive racism pushed a mentally unstable Ferguson over the edge").

${ }^{7}$ See Sherman, supra note 2, at A6 (describing the 1846 New York case). A jury found the accused, William Freeman, sane and guilty of murdering four whites, but the appellate court reversed and remanded on the grounds that the sanity hearing had been improperly conducted. See id. Before a retrial, however, Freeman died of tuberculosis and an autopsy revealed a brain disease. See id. The appellate court then ruled Freeman insane as a result of brutalization by whites. See id.

${ }^{8}$ See GRIER \& COBBS, supra note 4, at $154-80$ (focusing on mental illness and treatment). Unlike Ferguson's former attorneys, Grier and Cobbs treat black rage as a mental disease independent of an underlying mental condition. See id. 
intended to persuade the jury that their client should not be held accountable for his actions on the ill-fated train car. ${ }^{9}$

As might be expected, the prospect of a black rage defense has drawn both criticism and praise. Many find the defense demeaning to blacks, exhuming "ancient stereotypes of the 'crazy nigger,' childlike primitive, straight out of D.W. Griffith's Birth of a Nation, unable to control his hot-blooded tropical lusts." 10 Indeed, depictions of the black race as susceptible to uncontrollable rage and prone to violence may inadvertently justify white fear of blacks and thus further racist attitudes. ${ }^{11}$ Although a majority of Americans express a general distaste for attempts to excuse criminal conduct by portraying the defendant as a victim, others find the black rage defense "compelling." 12 They celebrate the defense as a political legitimization of aggressive responses to racial oppression, noting that the appropriate flip side to black rage is white guilt and fear. ${ }^{13}$

In addition to touching upon highly political and sensitive issues like race and crime, this widely publicized defense typifies an increasingly popular trend in the criminal law whereby the perpetrator of a crime depicts himself ${ }^{14}$ as a victim in order to escape criminal responsibility. ${ }^{15}$ These victimization defenses-drawing

${ }^{9}$ See, e.g., Sherman, supra note 2, at A6 (describing the trial tactics of Ferguson's former attorneys).

${ }^{10}$ Clarence Page, "Black Rage" May Be Real but No Rationale for Murder, RockY MountaIn News, June 23, 1994, at 43A; see also Alan M. DERShowITZ, THE ABUSE EXCUSE AND OTHER COP-OUTS, SOB STORIES AND EVASIONS OF RESPONSIBILITY 90 (1994) ("[T]he 'black rage' variation on the abuse-excuse defense is an insult to millions of law-abiding black Americans.").

${ }^{11}$ See DERSHOWTrZ, supra note 10, at 90 ("[I]f blacks as a group have more 'rage' than others, and are thus more inclined toward violence, some racists will argue for longer sentences for black recidivists, earlier and harsher police intrusion against black suspects, and other forms of 'preventive' intervention in black neighborhoods."); Law E' Order (NBC television broadcast, Feb. 1, 1995) ("[I]t's you who are giving all the bigots in this country the justification for their fear and hatred.") (statement of prosecutor to black rage expert witness).

12 Poll: Defendants as Victims No Defense, UPI, Apr. 11, 1994, available in LEXIS, Nexis Library, Curnws File. Forty-five percent of whites and sixty-eight percent of blacks surveyed reported that they were receptive to the black rage defense. See id.

is See Eric Pooley, Capitalizing on a Killer: A Spurious "Black Rage" Defense, NEwSDAY (N.Y.), Apr. 18, 1994, at 38 (attributing this position to civil rights activists Al Sharpton, Vernon Mason, and Colin Moore). Some criticize the black rage defense for this very same reason. See DERSHOWIT, supra note 10, at 27 (criticizing the black rage defense as encouraging vigilante justice); Pooley, supra, at 38 (arguing that Ferguson's attorneys and civil rights leaders have overly politicized and manipulated the Ferguson case).

${ }^{14}$ For clarity and consistency with the discussion of Ferguson, masculine generic personal pronouns appear throughout this Comment.

${ }^{15}$ See, e.g., DERSHOWITZ, supra note 10, at 3 (criticizing the trend); Niko Price, The 
upon a self-defense theory to justify criminal behavior ${ }^{16}$ or drawing upon an insanity theory to excuse criminal behavior ${ }^{17}$-range from the widely accepted to the highly laughable and seem to accommodate any set of circumstances. ${ }^{18}$ Consequently, victimization defenses like the black rage defense have the dangerous potential

“Abuse Excuse”: Threat to Justice?, Legal INTELLIGENCER, May 31, 1994, at 3 (citing a number of legal observers who are also critical of this trend).

${ }^{16}$ These defenses are known in criminal law as justifications. See JOSHUA DRESSLER, UNDERSTANDING CRIMINAL LAW 180 (1987) ("U]Justified conduct is conduct that under ordinary circumstances is criminal but which under the special circumstances that constitute the justification defense is not wrongful and, perhaps, is even affirmatively desirable."); see also Michael S. Moore, Causation and the Excuses, 73 CAL. L. REv. 1091, 1095-96 (1985) (distinguishing between criminal law justifications and excuses); infra notes 45-50 and accompanying text (discussing criminal law justifications).

Self-defense theory exculpates the defendant who is not the aggressor and who reasonably believes that his use of force is necessary to repel the imminent and unlawful use of force by the aggressor. See DRESSLER, supra, at 191 (listing the elements of the self-defense justification). Victimization justifications, such as the battered person's syndrome raised by Lorena Bobbitt and the Menendez brothers, try to extend self-defense theory by relaxing the requirement of imminent danger, see, e.g., Rocco C. Cipparone, Jr., Comment, The Defense of Baltered Women Who Kill, 135 U. PA. L. REV. 427, 436-39 (1987) ("Imminence does not mean inevitability or certainty ...."), and by injecting subjectivity into the requirement of reasonable belief, see, e.g., State v. Kelly, 478 A.2d 364, 378 (N.J. 1984) (admitting expert testimony on the battered woman's syndrome that "could significantly affect the jury's evaluation of the reasonableness of defendant's fear for her life"). For a discussion of the battered woman's syndrome justification, see DRESSLER, supra, at 203-05 and the sources cited therein.

17 These defenses are known in the criminal law as excuses. See DRESSLER, supra note 16, at 183 ( ${ }^{\text { }}[\mathrm{E}] \mathrm{xcused}$ conduct is wrongful and unjustified conduct that causes social harm but for which the actor is not held personally to blame."); see also Moore, supra note 16, at 1097-99 (delineating the criminal law excuses); infra notes 51-55 and accompanying text (discussing criminal law excuses).

Insanity exculpates the defendant whom the court finds to be seriously mentally ill. Victimization excuses try to work a pattern of victimization into this framework, claiming that a history of abuse has driven the defendant-victim legally insane. Although these defenses generate more controversy than do the victimization justifications, they have been subject to considerably less legal analysis. See, e.g., Maria Massucci \& James A. Pitaro, Note, Victimization as a Defense: Valid Protection for the Innocent or Escape from Criminal Responsibility?, 8 ST. JOHN'S J. LEGAL COMMENT. 305, 326-36 (1992) (discussing post-partum depression and acute grief syndrome).

${ }^{18}$ For a catalogue of victimization defenses, see DERSHOWITZ, supra note 10, at 321-41 (describing and assessing a litany of "abuse excuses," including Chronic Lateness Syndrome, Football Widow Syndrome, and UFO Survivor Syndrome); see also Price, supra note 15, at 3 (discussing the "urban survival syndrome" raised by an inner-city Texas youth on trial for the hasty murder of two unarmed men); Margot Slade, At the Bar: In a Growing Number of Cases, Defendants Are Portraying Themselves as the Victims, N.Y. TIMES, May 20, 1994, at B20 (discussing the meek-mate defense successfully raised in a California case by a psychologically emasculated husband on trial for the murder of his wife). 
to "weaken traditional beliefs about personal responsibility, increase lawlessness by creating a license for vigilante violence, and 'undercut the credibility of legitimate defenses in appropriate cases."

This Comment analyzes how black rage fits into the existing criminal law and suggests that its introduction produces a troubling result. Part I discusses the psychiatric and sociological underpinnings of black rage and explores possible roles for a black rage defense in the criminal law. Part II argues that the black rage defense fits neatly into the family of insanity defenses, applies the requirements of the several insanity tests to black rage, and compares black rage to similar mental conditions that commonly pass these tests. Part II then argues that black rage also fits into a diminished capacity role, meeting the requirements of the Model Penal Code test for mitigating murder to voluntary manslaughter. Part III analyzes these results under both utilitarian and retributivist lenses, suggesting that black rage differs from legally recognized varieties of insanity in important respects. Part III then balances the competing interests of the two penal theories and proposes an acceptable solution.

\section{BLACK RAGE AND THE BLACK RAGE DEFENSE ${ }^{20}$}

\section{A. The Psychiatric and Sociological Basis for Black Rage}

Black rage describes a mental disturbance caused by long-term exposure to societal racism. Psychiatrists William $H$. Grier and Price M. Cobbs first formally advanced the notion of a mental condition defined by black rage in $1968 .{ }^{21}$ Grier and Cobbs wrote

${ }^{19}$ James Andrews, I May Be a Murderer, but It's Not My Fault, CHRISTIAN SCI. MONITOR, Sept. 19, 1994, at 13, 13 (quoting Alan Dershowitz); see also DERSHOWITZ, supra note 10, at 27-29 (expressing his concerns as a civil libertarian, defense lawyer, and egalitarian).

${ }^{20}$ Ferguson's attorneys had hoped to argue that Ferguson's black rage merely exacerbated a pre-existing mental condition. See Pooley, supra note 13, at 38 (quoting William Kunstler, one of Ferguson's former defense attorneys, as assuring whites that "Ferguson's rage was simply a catalyst for violence resulting from a pre-existing mental illness"); CNN News, supra note 6 ("[T]his kind of rage can trigger off a mentally ill person, even to kill." (quoting Kunstler)); Kuby Telephone Interview, supra note 5 (opining that, as a practical matter, it would be "impossible to imagine" a jury accepting black rage as a stand-alone illness). Thus, Ferguson's planned insanity defense differed from the stand-alone black rage defense on which this Comment focuses. But see DERSHOWITZ, supra note 10, at 90 (seeing little difference between rage producing violent crime by itself and rage acting as a catalyst for violent crime).

${ }_{21}$ See GRIER \& COBBS, supta note 4, at 200-13. 
that blacks in America must develop a "healthy' cultural paranoia" as a coping mechanism to deal with constant racial stress:

[I]t is necessary for a black man in America to develop a profound distrust of his white fellow citizens and of the nation.... If he does not so protect himself, he will live a life of such pain and shock as to find life itself unbearable. For his own survival, then, he must develop a cultural paranoia in which every white man is a potential enemy unless proved otherwise and every social system is set against him unless he personally finds out differently. ${ }^{22}$

In coping with this racial stress, blacks must continually endure subtle racism such as being passed up by cabs or being taken as shoplifters in stores. ${ }^{23}$ These subtle insults send a recurring message that blacks are inferior, fueling a resentment within the black psyche that can cause depression, grief, and rage. ${ }^{24}$ Consequently, Grier and Cobbs foretold, "As a sapling bent low stores energy for a violent backswing, blacks bent double by oppression have stored energy which will be released in the form of rage-black rage, apocalyptic and final. ${ }^{25}$

${ }^{22}$ Id. at 177-78; see also Sylvia Adcock, "Black Rage" Strategy: New Insanity Defense in LIRR Massacre, NEWSDAY (N.Y.), Mar. 15, 1994, at 7 (synopsizing Grier and Cobbs's black rage theory).

${ }^{23}$ See Alexander, supra note 4, at B4 (calling these day-to-day examples of discrimination "micro insults"); see also Ellis Cose, I Have This Rage, ATLANTA J. \& CoNST., Nov. 28, 1993, at F1 (making a black rage argument before the L.I.R.R. massacre occurred).

${ }^{24}$ See GrIER \& COBBS, supra note 4, at 209-10 (detailing the sources and implications of black rage); Alexander, supra note 4, at B4 (same); Alvin F. Poussaint, Blackon-Black Homicide: A Psychological-Political Perspective, 8 VICTIMOLOGY 161, 163 (1983) ("[I]nstitutional racism . . . fosters a chronic lack of Black self-respect, predisposing many poor Blacks to behave self-destructively and with uncontrollable rage." ); Law $\mathcal{E}^{2}$ Order, supra note 11 ( $\mathrm{A}$ lifetime of suffering the indignities of a racist society; eventually the kettle boils over . . . the experts call it "black rage."); see also Richard Delgado, "Rotten Social Background": Should the Criminal Law Recognize a Defense of Severe Environmental Deprivation?, 3 LAW \& INEQ. J. 9, 35 (1985) (noting that "[h] umans subjected to stress and danger become irritable and aggressive" and citing studies to this effect).

${ }^{25}$ GRIER \& COBBS, supra note 4, at 210; see also Law E Order, supra note 11 ("Eventually [a black man's self-hatred] is redirected outward toward [his] tormentors. Some individuals can't help but lash out at the symbols of their torment.").

More recently, psychiatrists have taken a less violent and less dramatic view: "Most blacks take a healthy point of view on dealing with discrimination and racism ... tak [ing] their anger and rage and us[ing] it constructively, working harder in a job or using it as an incentive to acquire better skills in a particular area." Alexander, supra note 4, at B4 (quoting Alvin F. Poussaint, Associate Professor of Psychiatry at Harvard University); see also JAMES P. COMER \& ALVIN F. POUSSAINT, BLACK CHILD CARE: How to BRING UP A HeAlThY BlaCk CHILd IN AMERICA 64 (1975) (suggesting that parents channel "early negative behavior, anger, and aggression" into 
Unlike the America that causes black rage, the black rage phenomenon does not discriminate by class. Indeed, well-to-do blacks are not immune from black rage: they may continue to harbor "deep-seated anger, frustration, and isolation ... despite . . . outward trappings of success. ${ }^{26}$ In addition to the stress of constant discrimination, successful blacks may face corporate glass ceilings designed to prevent black promotions; "continued exclusion from the old-boy network[s]; . . problems coping with [their] own cultural and racial identity; ... . [and] the realization that the next generation of blacks will probably have to deal with the same issues of racism and exclusion from society. ${ }^{27}$ These additional stressors operate to fuel further the class-blind condition called black rage.

This formal psychiatric and sociological recognition of black rage only confirms what black writers have been expressing for years. In novels like Richard Wright's Native $\operatorname{Son}^{28}$ and plays like LeRoi Jones's Dutchman, ${ }^{29}$ black literature has dramatically depicted the phenomenon. For example, frustrated by the attractive but offlimits white world of urban Chicago, Native Son's Bigger Thomas describes his pent-up feelings:

Every time I think about [the disparity between blacks and whites] I feel like somebody's poking a red-hot iron down my throat.... We live here and they live there. We black and they white. They got things and we ain't. They do things and we can't. It's just like living in jail.

... Sometimes I feel like something awful's going to happen to me. ... Naw; it ain't like something going to happen to me. ... It's like I was going to do something I can't help. ${ }^{30}$

"socially acceptable, useful energy").

${ }^{26}$ Francine L. Pope, The Disillusioned Black Middle Class, Boston Globe, Mar. 1, 1994, at 56 (reviewing Ellis COSE, THE RAGE OF A PRIvILEGED ClASs (1993)); see also Law $\mathcal{E}^{\prime}$ Order, supra note 11 ("[The successful black man] is just as angry and just as likely to explode [as any other black man].").

${ }^{27}$ Pope, supra note 26, at 56; see also Cose, supra note 23, at F1.

${ }^{28}$ RICHARD WRIGHT, NATIVE SON (1940) (depicting a black male protagonist who explodes in a violent rage, kills two women, and ultimately dies in the electric chair).

${ }^{29}$ LEROI JONES, DUTCHMAN, reprinted in LEROI JONES, DUTCHMAN AND THE SLAVE 3 (1964) (depicting a black male protagonist who vents his rage in a New York City subway car).

so WRIGHT, supra note 28, at 23-24. In the author's introduction, Wright explains the reasons for Bigger's condition: "[G]ranting the emotional state, the tensity, the fear, the hate, the impatience, the sense of exclusion, the ache for violent action, the emotional and cultural hunger, Bigger Thomas, conditioned as his organism is, will not become an ardent, or even a lukewarm, supporter of the status quo." Id. at $\mathrm{xx}$. 
Similarly, after being called "Uncle Tom Big Lip," Dutchman's Glay Williams reveals his more middle-class rage:

If I'm a middle-class fake white man. . . . Let me be who I feel like being. Uncle Tom. Thomas. Whoever. It's none of your business. You don't know anything except what's there for you to see. An act. Lies. Device. . . . And I sit here, in this buttoned-up suit, to keep myself from cutting all your throats. ${ }^{31}$

Like the psychiatrists and sociologists, literature often locates the cause of black rage in white discrimination and oppression:

The white neighbor decided to limit the amount of education his black neighbor could receive; decided to keep him off the police force and out of the local national guards; to segregate him residentially; to Jim Crow him in public places; to restrict his participation in the professions and jobs; and to build up a vast, dense ideology of racial superiority that would justify any act of violence taken against him to defend white dominance; and further, to condition him to hope for little and to receive that little without rebelling ....

... [This] oppression spawned among [blacks] a myriad variety of reactions, reaching from outright blind rebellion to a sweet, other-worldly submissiveness. ${ }^{32}$

\section{B. Fitting Black Rage into the Criminal Law}

In fitting black rage into the criminal law, one must consider the philosophies driving traditional notions of crime and punishment and the resulting rationales for exculpating certain actors. This Section meets both challenges, setting the stage for a discussion of specific roles available in the criminal law for a black rage defense.

${ }^{31}$ JONES, supra note 29 , sc. 2, at 34 .

32 WRIGHT, supra note 28 , at xii. Among the myriad variety of reactions to oppression, Wright includes turning to religion, to alcohol, to education, and to music. See id. at xii-xiii.

As for turning to music, see JONEs, supra note 29, sc. 2, at 35 ("All the hip white boys scream for Bird [jazz saxophonist Charlie Parker]. And Bird saying, 'Up your ass, feeble-minded ofay! Up your ass.' . . . Bird would've played not a note of music if he just walked up to East Sixty-seventh Street and killed the first ten white people he saw."); WYNTON MARSALIS, The New Orleans Function: Premature Autopsies (Sermon), on THE MAJESTY OF THE BLUES (Columbia Records 1989) ("[W]hen a majestic sound takes the field, . . . ears begin to change and lives begin to change and those who were musically lame begin to walk with a charismatic sophistication to their steps."). 


\section{Utilitarianism, Retributivism, and Free Will}

Utilitarianism and retributivism constitute the two major penal theories driving traditional notions of crime and punishment. ${ }^{33}$ Under the utilitarian theory, the "purpose of all laws is to maximize the net happiness of society. "34 Accordingly, utilitarians justify punishment only insofar as "it promises to exclude some greater evil. " 35 Thus, in application, utilitarians believe in general deterrence-punishing wrongdoers so that other potential wrongdoers will forego future criminal conduct; specific deterrence-punishing wrongdoers so that they will forego future criminal conduct; and rehabilitation-reforming wrongdoers so that they will forego future criminal conduct. ${ }^{36}$

Retributivism, in contrast, focuses on the notions of just deserts and moral blameworthiness. ${ }^{37}$ Under the retributive theory, "punishment of a wrongdoer is justified because the offender deserves to be punished ... because he committed a crime. ${ }^{n 38}$ Thus, unlike utilitarians who look ahead to future criminal conduct, retributivists look back to the specifics of the crime committed, gauge the moral blame associated with that crime, and punish the deserving criminal actor accordingly-unconcerned with any net societal gain. ${ }^{39}$

3s See generally DRESSLER, supra note 16, at 3-12 (discussing the premises behind and manifestations of these theories); SANFORD H. KADISH \& STEPHEN J. SCHULHOFER, Criminal LAW AND ITS Processes: Cases and Materials 136-65 (5th ed. 1989) (excerpting various utilitarian and retributivist theorists). Denunciation and incapacitation are other, less influential penal theories. See DRESSLER, supra note 16, at 8 (discussing denunciation-a theory "that punishment is justified as a means of expressing society's condemnation of a crime"); KADISH \& SCHULHOFER, supra, at 160. 65 (discussing incapacitation-a theory that punishment is justified as a means of insulating society from a criminal actor).

${ }^{3}$ DRESSLER, supra note 16, at 4; see also JEREMY BENTHAM, An Introduction to the Principles of Morals and Legislation, in THE UTILITARIANS 162 (1961) ("The general object which all laws have, or ought to have, in common, is to augment the total happiness of the community ....").

${ }_{35}$ BENTHAM, supra note 34 , at 162; see also DRESSLER, supra note 16 , at 5 ("[Utilitarians justify punishment] if, but only if, the pain suffered by [those punished] will be less than the pain to be experienced by society due to the commission of future crimes that is avoided as the result of the punishment.").

${ }^{36}$ See DRESSLER, supra note 16, at 5-6 (considering the many forms of utilitarian theory).

${ }^{37}$ See generally id. at 6-8 (discussing the premises and forms of retributivist theory); IMMANUEL KANT, THE METAPHYSICAL ELEMENTS OF JUSTICE 99-107 (John Ladd trans., 1965) (setting forth Kant's "right to punish," the leading exposition of retributivism).

${ }^{38}$ DRESSLER, supra note 16, at 6; see also MICHAEL.S. MOORE, LAW AND PSYCHIATRY $236(1984)\left({ }^{\prime}[R]\right.$ etributivism asserts that punishment is properly inflicted because, and only because, the person deserves it.").

${ }^{39}$ See DRESSLER, supra note 16 , at 7 (evaluating "an eye for an eye, a tooth for a 
Essential to both penal theories is a belief in the existence of free will. ${ }^{40}$ Without free will, the deterrent effect of utilitarianism breaks down because actors can no longer choose to forego criminal conduct in order to avoid criminal punishment. ${ }^{41}$ Likewise for retributivism, without free will, the rationale for punishment disappears-a criminal actor cannot, and should not, take moral blame for actions over which he has no control. ${ }^{42}$

\section{Justification and Excuse}

The utilitarian and retributivist notions that justify the punishment of certain actors imply that certain otherwise punishable criminal conduct should go without punishment. These exculpatory circumstances constitute the criminal law's true defenses: defenses that, if proven, produce an acquittal even though the prosecution has proven every element of its prima facie case. ${ }^{43}$ Of the true defenses, the two categories into which black rage may potentially fit are justifications and excuses. ${ }^{44}$

Justifications are special circumstances which entitle one to act in a way normally considered wrong and criminal. ${ }^{45}$ For example, an actor is entitled to use self-defense when faced with a threat of unlawful force, necessitating an immediate use of force to protect himself against the aggressor. ${ }^{46}$ Similarly, an actor is entitled to engage in what is normally criminal conduct if the injury that might reasonably result from such conduct is less than the threatened

tooth" and other articulations of retributivism).

${ }^{10}$ See id. at 5 (noting the utilitarian belief that human beings act rationally and hedonistically and "will avoid criminal activity if the perceived potential pain (punishment) outweighs the potential pleasure (criminal rewards)"); id. at 6 ("Critical to retributive theory is the fact that human beings possess free will-i.e., their conduct is not determined by factors external to their will.").

${ }^{41}$ See BENTHAM, supra note 34, at 162 ("[P]unishment ought not to be inflicted . . . [w] here it must be inefficacious: where it cannot act so as to prevent the mischief.").

12 See DRESSLER, supra note 16, at 6 ("[Under retributivism, p]unishment is deserved because the wrongdoer made the choice to commit the offense.").

43 See id. at 176 (describing "true defenses"). True defenses differ from case-inchief "defenses" which negate the prosecution's prima facie case and thus are technically not defenses at all. See id. at 175-76.

44 The other two categories of true defenses are crime-specific defenses, such as legal impossibility and abandonment of criminal enterprise, and extrinsic policydriven defenses, such as statutes of limitations and diplomatic immunity. See id. at 177-78 (discussing these defenses); see also Moore, supra note 16, at 1097 (same).

15 See DRESSLER, supra note 16, at 176-77 (describing justification defenses); Moore, supra note 16, at 1096 (same).

${ }^{46}$ See, e.g., MODEL PENAL CODE $§ 3.04$ (1962) (self-defense provision). 
public or private injury avoided. ${ }^{47}$ Thus justified, an actor is neither wrong nor criminal; he acts in a socially acceptable way and confers upon society a net benefit. ${ }^{48}$ As a result, the justified actor merits neither punishment from the utilitarian in that the actor has maximized societal happiness and prevented a greater evil, ${ }^{49}$ nor punishment from the retributivist in that the actor has acted morally and blamelessly. ${ }^{50}$

Excuses, in contrast to justifications, deal with wrongful, unjustified actions that cause a net social harm for which the actor is nevertheless held not accountable. ${ }^{51}$ These excused actors escape liability because of their subjective mental states: they act out of mistake, ${ }^{52}$ out of compulsion, ${ }^{53}$ or otherwise without the requisite "moral blameworthiness" usually associated with wrongdoers. ${ }^{54}$ Accordingly, both the utilitarian and the retributivist exculpate the excused actor: mistakes, compulsions, and mental defects both make deterrents ineffective and mitigate moral blameworthiness. ${ }^{55}$

Because conduct driven by black rage will generally fall short of the net societal betterment required by the justification defensesindeed, there is rarely societal benefit gleaned from rages-one cannot categorize the black rage defense as a justification. ${ }^{56}$ If a

17 See, e.g., \$ 3.02(1) (necessity provision).

18 See DRESSLER, supra note 16 , at $176-77$ (considering the merits of justification); Delgado, supra note 24, at 15 ("Justification defenses hold the defendant accountable because by acting unlawfully, he or she furthered an important social interest."); Moore, supra note 16, at 1096 ("Justifications answer the general evaluative question of whether, all things considered, the world is better or worse than it was without the action in question.").

${ }^{19}$ See supra notes 33-36 and accompanying text (discussing utilitarian weighing of net societal good).

${ }^{50}$ In fact, because justified actors act morally and blamelessly and confer upon society a net benefit, society not only refuses to punish them, but also encourages their actions. See DRESSLER, supra note 16, at 177, 180 (commenting on society's treatment of justified actors).

${ }^{51}$ See DRESSLER, supra note 16, at 183 (noting that most societal explanations for excuses are couched in non-utilitarian terms); Delgado, supra note 24 , at 16 ("With excuses . . . the defendant is excused because, as a result of circumstances beyond his or her control, it is not fair to hold the actor responsible for the criminal act."); Moore, supra note 16, at 1096 ("[Excuses answer the question of whether there is] a culpable actor who is responsible for making the world worse than it was without the act ..... ).

52 See, e.g., MODEL PENAL CODE $§ 2.04$ (1) (mistake provision).

${ }^{53}$ See, e.g., $\$ 2.09$ (duress provision).

51 DRESSLER, supra note 16, at 177; see also MODEL PENAL CODE $\$ 4.01$ (insanity provision).

${ }^{35}$ See, e.g., supra note 41 and accompanying text (noting that utilitarians do not favor punishment where it would be an ineffective deterrent).

${ }^{36}$ To be sure, if black rage-driven criminal conduct miraculously put an end to all 
black rage actor can demonstrate that his rage supplanted or lessened his moral blameworthiness, however, his act may fit neatly into the category of excuse defenses. ${ }^{57}$

\section{ANALYSIS UNDER THE EXISTING LAW ${ }^{58}$}

Since black rage is not a justification, one must turn to the specific excuse defenses in the criminal law to determine the

racism, one could persuasively argue that the rage conferred a net societal betterment. This necessity argument, however, turns on the reasonableness of the actor's ex ante belief that the harm sought to be avoided can actually be avoided by his proposed criminal conduct. See MODEL PENAL CODE § 3.02(1)(a) (stating the necessity provision). Because this belief is aspirational, but not reasonable, such a necessity defense would fail at least the Model Penal Code formulation of justification.

${ }^{57}$ In addition to an excuse role, black rage may play two other roles in criminal law. First, the special circumstances surrounding black rage may appropriately figure into a sentencing calculus wholly independent of a determination of guilt or innocence. See DERSHOWITZ, supra note 10, at 6 ("A history of abuse is not a psychological or a legal license to kill. It may, in some instances, be relevant at sentencing, but certainly not always."). Or second, quite apart from any underlying criminal law, the jury may "exercise its constitutionally mandated power to nullify existing law" by ignoring the judge's instructions and returning a not-guilty verdict for a guilty defendant. Chaya Weinberg-Brodt, Note, Jury Nullification and JuryControl Procedures, 65 N.Y.U. L. REv. 825, 827 (1990) (arguing that a defendant has a Sixth Amendment right to appeal to a jury in order to nullify existing law); see also Robert G. Morvillo, Jury Nullification, N.Y. L.J., June 7, 1994, at 3 (analyzing black rage as a jury nullification "defense"). See generally Jack B. Weinstein, Considering Jury "Nullification": When May and Should a Jury Reject the Law to Do Justice, 30 AM. CRIM. L. REV. 239 (1993) (examining the role of jury nullification in criminal trials).

Because these roles are not traditional criminal law defenses, they are outside the scope of this Comment. They remain, however, viable alternatives to traditional defenses for the use of black rage in the criminal law.

${ }^{58}$ Because black rage is a recently identified mental condition, resting in part on psychiatry and in part on sociology, admissibility obstacles could prove troublesome. See FED. R. EvID. 702 (governing expert testimony in federal courts); Daubert v. Merrell Dow Pharmaceuticals, Inc., 113 S. Ct. 2786, 2794 (1993) (setting the current, flexible standard for the admission of expert testimony in federal courts); Frye v. United States, 293 F. 1013 (D.C. Cir. 1923) (setting the older, stricter federal standard still followed in some jurisdictions). This question, though, is outside of the scope of this Comment and has been answered-in the affirmative-by existing analyses of post-traumatic stress disorder and the like. See David McCord, Syndromes, Profiles and Other Mental Exotica: A New Approach to the Admissibility of Nontraditional Psychological Evidence in Criminal Cases, 66 OR. L. REV. 19 (1987) (setting forth a new "four factor balancing test" for the admissibility of nontraditional evidence); Michael J. Davidson, Note, Post-Traumatic Stress Disorder: A Controversial Defense for Veterans of a Controversial War, 29 WM. \& MARY L. REV. 415, 434-37 (1988) (assessing evidentiary concerns surrounding post-traumatic stress disorder); Massucci \& Pitaro, supra note 17, at 322. 26 (assessing the evidentiary concerns of the battered person's syndrome); see also U.S. CONST. amend. VI ("In all criminal prosecutions, the accused shall enjoy the right ... to have compulsory process for obtaining witnesses in his favor . ..."). 
possible applications of a black rage excuse defense. Two particular excuses, insanity and diminished capacity, hold the most promise for a successful black rage defense. ${ }^{59}$

Both insanity and diminished capacity operate by demonstrating a less than usual sense of moral blameworthiness-and thus legal responsibility-resulting from a mental illness or deficiency that seriously interferes with free will. ${ }^{60}$ The insane actor, his free will largely undermined by the operation of a mental disease or defect, acts without moral blameworthiness and is therefore completely exonerated. ${ }^{61}$ In contrast, the diminished capacity actor, his free will affected but not fully eclipsed, acts with less than usual moral blameworthiness and accordingly may deserve partial exoneration. ${ }^{62}$ Black rage, entailing lost control of behavior and impaired ability to reason, contains elements of both excuse defenses. Accordingly, the remainder of this Comment focuses on these two defenses: first analyzing black rage under existing insanity and diminished capacity laws and second determining whether these results are consistent with the policies and theories underlying the criminal law.

\section{A. The Black Rage Defense as an Insanity Defense}

Of the two excuse roles discussed above, the completely exculpating insanity role presents itself to the black rage defendant as the more attractive alternative. Accordingly, this Section focuses on black rage as an insanity defense, first explaining and applying the several insanity tests to determine whether black rage can qualify as legal insanity. The Section then proceeds to compare black rage to other recognized varieties of legal insanity, demonstrating that black rage is a similar mental condition and thus deserves similar treatment under the criminal law.

${ }^{59}$ Other excuse defenses, such as duress and intoxication, have little if any application to black rage and thus are not discussed in this Comment. For a discussion of these defenses, see DRESSLER, supra note 16, at 259-88.

${ }^{60}$ See supra notes 40-42 and accompanying text (discussing moral blameworthiness and its relationship to free will).

${ }^{61}$ See DRESSLER, supra note 16, at 295-96 (discussing the rationales behind the insanity defenses); infra part II.A.1 (delineating the insanity tests).

62 See DRESSLER, supra note 16, at 325-27; infra part II.B (discussing diminished capacity). The diminished capacity defense is only available in some states, and even then only as a partial defense to a murder charge. See DRESSLER, supra note 16, at 325 (discussing the limitations placed on diminished capacity); infra notes 156-62 and accompanying text (same). 


\section{Explanation and Application of the Insanity Tests}

Each of the insanity tests requires that the actor suffer from a mental disease or defect impairing his ability to act rationally or control his behavior. ${ }^{63}$ Consequently, a legal determination of insanity-a legal term of art-necessarily relies to some extent on psychiatry. ${ }^{64}$ In the Diagnostic and Statistical Manual of Mental Disorders, ${ }^{65}$ the American Psychiatric Association characterizes a mental disorder as "a behavioral or psychological syndrome or pattern in an individual which usually includes either a painful symptom or impairment in important areas of functioning. ${ }^{.66}$ In adapting this and similar medical definitions to the law of insanity, some courts, legislatures, and other institutions have variously defined the legal requirements of insanity: vaguely, as a "disease of the mind ${ }^{n} ;{ }^{67}$ more specifically, as "any abnormal condition of the mind which substantially ... impairs behavior controls"; ${ }^{78}$ or not at all. ${ }^{69}$

Before reaching the merits of the several insanity tests, black rage must first meet the threshold "disease of the mind" requirement, for which "usually only a limited number of psychoses and the most extreme forms of mental defect can qualify. ${ }^{n 0}$ This presents an initial problem for black rage in that it is not listed in the

${ }^{63}$ See DRESSLER, supra note 16, at 298 (explaining the legal definition of mental disease or defect).

${ }^{64}$ See id. at 297-98 (noting that "mental illness" is a term used by the psychiatric community, whereas "insanity" is a legal term).

${ }^{65}$ AMERICAN PSychiatric Ass'N, Diagnostic and Statistical ManUal of MENTAL DISORDERS (4th ed. 1994) [hereinafter DSM-IV].

${ }^{66}$ DRESSLER, supra note 16, at 298 (citing AMERICAN PSYCHIATRIC Ass'N, Diagnostic and Statistical Manual of Mental Disorders 5 (3d ed. 1980) [hereinafter DSM-III]).

${ }^{67}$ M'Naghten's Case, 8 Eng. Rep. 718, 722 (H.L. 1843) (establishing the M'Naghten test discussed infra part II.A.1.a); see also ABRAHAM S. GOLDSTEIN, THE INSANITY DEFENSE 47-49 (1967) (complaining that there has been almost no judicial elaboration of the term "mental disease").

${ }^{68}$ McDonald v. United States, 312 F.2d 847, 851 (D.C. Cir. 1962).

${ }^{69}$ See, e.g., MODEL Penal CoDe $\$ 4.01$ explanatory note (1962) (leaving the issue of insanity "open to accommodate developing medical understanding"). Arguably, having no definition of the requirements of legal insanity is as unhelpful as having a vague definition. See supra note 67 and accompanying text.

${ }^{70}$ GOLDSTEIN, supra note 67, at 47-48 (noting that this "definition" of disease of the mind comes not from the disease of the mind prong but from the more detailed knowledge prong); see also WAYNE R. LAFAVE \& AUSTIN W. SCOTT, JR., CRIMINAL LAW 312 (2d ed. 1986) (noting that only a few psychoses qualify "not because certain illnesses or defects are per se excluded but rather because they do not produce the lack of cognition required"). 
Diagnostic and Statistical Manual of Mental Disorders-the resource on which courts and psychiatrists heavily rely in determining legal insanity. However, this problem can be overcome in appropriate cases through qualified expert testimony, either by likening black rage to other varieties of insanity ${ }^{71}$ or by measuring a particular case of black rage against a definable set of black rage characteristics, perhaps to be developed by psychiatrists at some point in the near future. ${ }^{72}$

7 See, e.g., United States v. Robertson, 507 F.2d 1148, $1153-56$ (D.C. Cir. 1974) (acknowledging psychiatric testimony diagnosing a case of black rage as schizophrenia-a psychosis); United States v. Alexander, 471 F.2d 923, 957-58 (D.C. Cir.) (recounting psychiatric testimony diagnosing black rage as akin to emotional illness), cert. denied, 409 U.S. 1044 (1972); Sherman, supra note 2, at A6 (noting an $1846 \mathrm{New}$ York case as perhaps the first to hold a black rage defendant insane).

In Robertson, the defendant-a black man-became involved in a pool hall fight, returned there a half-hour later, and shot and injured one white man. Robertson then jumped into his car and drove erratically through downtown Washington, causing a multiple-car accident. Following this accident, Robertson shot and killed another white man who was standing motionless by the parked car Robertson had just hit. See Robertson, 507 F.2d at 1150. To his psychiatrist, Robertson explained, "They have arrested me and by this trial seek my elimination. . . . If a black man kills a white man, it is not a crime. It is getting the oppression off his neck. If a black man kills a black man, it is murder." Id. at 1154. After the United States Court of Appeals for the District of Columbia Circuit remanded to hold insanity hearings, Robertson refused to raise the insanity defense "for personal reasons of a quasi-political nature," feeling that such a defense would only denigrate his social protest. United States v. Robertson, 430 F. Supp. 444, 447-48 (D.D.C. 1977).

In Alexander, the defendants Alexander and Murdock-both black men-were sitting at the counter of a hamburger shop when five male marines and a woman-all white and perhaps all loud and drunk-entered. After a staredown between the defendants and the marines, the marines left the shop followed by the defendants. Fighting words and racial slurs ensued, escalating until Alexander drew a .38 revolver, shooting and killing two of the marines. See Alexander, 471 F.2d at 928-29. According to testimony of a treating psychiatrist, Murdock exhibited paranoid and sociopathic behavior. See id. at 957-58. The psychiatrist, however, failed to support this conclusion adequately, compelling the trial court to strike this testimony. See id. at 955. A jury found both Alexander and Murdock guilty and sane, and the United States Court of Appeals for the District of Columbia Circuit affirmed. See id. at 926, 928.

72 The experience of post-traumatic stress disorder is illustrative of this potentiality. Not listed in the Diagnostic and Statistical Manual of Mental Disorders until its third edition, see DSM-III, supra note 66, at 236-39, post-traumatic stress disorder is now accepted as a mental disease or defect within the meaning of the tests for legal insanity. See infra part II.A.2.c. Perhaps black rage will find its place in the fifth edition of the Manual. 


\section{a. The M'Naghten Test}

Over the years, several different formulations of the insanity test have evolved. The first modern formulation, articulated in 1843 by the English House of Lords in M'Naghten's Case, ${ }^{73}$ concerns itself solely with cognitive or mental-as opposed to volitional or willingability:

[T]o establish a defence on the ground of insanity, it must be clearly proved that, at the time of the committing of the act, the party accused was labouring under such a defect of reason, from disease of the mind, [1] as not to know the nature and quality of the act he was doing; or, [2] if he did know it, that he did not know he was doing what was wrong. ${ }^{74}$

Thus, in addition to a mental disease requirement, the M'Naghten test sets forth two largely redundant prongs: an actor must not know the nature and quality of his act-that is, that he was squeezing a human being as opposed to a lemon-or, alternatively, must not know that the act is legally or morally wrong. ${ }^{75}$ Application of the M'Naghten test remains far from straightforward, however, because its component terms-disease of the mind, ${ }^{76}$ know, ${ }^{77}$ and wrong ${ }^{78}$-are themselves far from straightforward. Although the M'Naghten test draws much criticism for being too narrow and

73 M'Naghten's Case, 8 Eng. Rep. 718 (H.L. 1843).

74 Id. at 722.

${ }^{75}$ See DRESSLER, supra note 16, at 299 (" [A]ny person who lacks [knowledge of the nature and quality of his act] will also 'fail' the right-wrong test, the second portion of the insanity definition."); GOLDSTEIN, supra note 67, at 50 ("[I]f the accused did not know the nature and quality of his act, he would have been incapable of knowing it was wrong.").

${ }^{76}$ See supra note 67 and accompanying text (noting that disease of the mind is a vague definition).

7 See DRESSLER, supra note 16, at 299 (distinguishing between narrow interpretations of knowledge-ability to describe verbally-and broader interpretations of knowledge-ability to evaluate in terms of impact on others); GoLDSTEIN, supra note 67, at 49-50 (same); LAFAVE \& Scotr, supra note 70, at 313-14 (same). Most courts addressing the issue have chosen the broader interpretation. See GoldSTEIN, supra note 67, at 49; LAFAVE \& SCOTT, supra note 70, at 313.

${ }^{78}$ See DRESSLER, supra note 16, at 299-300 (distinguishing between legal wrongs and moral wrongs); GOLDSTEIN, supra note 67, at 51-53 (same); LAFAVE \& SCOTT, supra note 70, at 314-16 (same). Legal wrongs will usually equal moral wrongs, with the notable exception of actions inspired by deific decrees, which are known to be legally wrong but by virtue of their source must be morally right. See, e.g., State v. Cameron, 674 P.2d 650, 652 (Wash. 1983) ("'[L]egally, I know, that it is against the law, but as far as right and wrong in the eye of God, I would say I felt no particular wrong." (quoting defendant Cameron)). 
outdated, it lately has enjoyed a renaissance of popularity precisely because it is so stringent. ${ }^{79}$

Under the M'Naghten formulation of the insanity test, black rage will satisfy the right-wrong prong of M'Naghten if the actor acts in an altered state of consciousness, for example, believing himself to be a leader in a racial war. ${ }^{80}$ Under the influence of such an altered state, right and wrong become blurred, and thus an actor may satisfy M'Naghten's second prong. Similarly, if a black rage defendant acts under a delusion of persecution or grandeur, for example, believing he is protecting himself from an illegal statewide conspiracy and thus misinterpreting his own and others' actions, he will also satisfy M'Naghten's right-wrong prong. ${ }^{81}$

\section{b. The Irresistible Impulse Test}

A second variation of the insanity test, the irresistible impulse test, usually appears as a third prong of the traditional M'Naghten test. This volitional prong broadens M'Naghten by including as insane actors those who act out of irresistible, uncontrollable impulses. ${ }^{82}$ According to typical jury instructions, an irresistible impulse must "completely deprive[] the person of the power of choice or volition." ${ }^{83}$ Consequently, "[i]f the accused would not have committed the act had there been a ... policeman present, he cannot be said to have acted under an irresistible impulse." 84 This prong, adopted in many M'Naghten jurisdictions, draws much criticism on the ground that psychiatrists-and philosophers-have

${ }^{79}$ See DRESSLER, supra note 16, at 296-97, 300 (attributing much of the renewed interest in the M'Naghten test to John Hinckley's assassination attempt on President Ronald Reagan and his subsequent acquittal on the grounds of insanity); KADISH \& SCHULHOFER, supra note 33, at 997 (same).

${ }^{80}$ See, e.g., United States v. Alexander, 471 F.2d 923, 957 (D.C. Cir.) ("[Murdock] was strongly delusional ... preoccupied with ... the idea ... that racial war was inevitable."), cert. denied, 409 U.S. 1044 (1972); United States v. Robertson, 430 F. Supp. 444, 445 (D.D.C. 1977) ("Robertson considered himself a 'Black Leader' who did not think it was murder to kill [a white] because [whites were] . . . not human. [Robertson therefore] viewed the shooting of [a white] as an attempt to put an 'underling' in his place.").

${ }^{81}$ See, e.g., infra note 119 (discussing Colin Ferguson's delusion of persecution as evidenced by his personal writings).

${ }^{82}$ See, e.g., Johnson v. State, 76 So. 2d 841, 844 (Miss.) (rejecting the irresistible impulse test in favor of the traditional M'Naghten test), cert. denied, 349 U.S. 946 (1955).

83 United States v. Kunak, 17 C.M.R. 346, 359 (C.M.A. 1954) (quoting jury instructions that elaborate slightly on earlier formulations of the test).

84 Id. (setting forth this so-called "policeman-at-the-elbow" formulation of the test). 
difficulty discerning between resistible and irresistible criminal urges. ${ }^{85}$

The irresistible impulse test affords the black rage defendant a second, volitional avenue through which to argue his insanity. This volitional prong lends itself well to black rage in that black rage may cause impulsive, uncontrollable behavior. ${ }^{86}$ A black rage defendant exhibiting such symptomology will satisfy this prong and thus the third prong addition to the $M$ 'Naghten test.

\section{c. The Model Penal Code Test}

The Model Penal Code of the American Law Institute embraces a third insanity test that incorporates both the cognitive element of the M'Naghten test and the volitional element of the irresistible impulse test. It reads:

A person is not responsible for criminal conduct if at the time of such conduct as a result of a mental disease or defect he lacks substantial capacity either to appreciate the criminality [wrongfulness] of his conduct or to conform his conduct to the requirements of law. ${ }^{87}$

The first prong-the appreciation of criminality-is a substantial revision of the M'Naghten test, collapsing its redundant prongs, substituting the more lenient "appreciate" for the stricter "know," and allowing jurisdictions the option to resolve the moral-legal question by inserting either "criminality" or "wrongfulness. ${ }^{88}$ The second prong-the conforming of conduct-restates the irresistible impulse test but avoids the ambiguous word "impulse. ${ }^{89}$ The Model Penal Code also modifies both of its prongs with "lacks

${ }^{85}$ See AMERICAN PSYChIATRIC AsS'N, StatEMENT ON THE INSANITY DEFENSE (1982), reprinted in ISSUES IN FORENSIC PSYCHIATRY 1, 16 (1984) (criticizing the irresistible impulse test); Herbert Wechsler \& Jerome Michael, A Rationale of the Law of Homicide: I, 37 Colum. L. Rev. 701, 754 (1937) (same).

${ }^{86}$ See, e.g., United States v. Alexander, 471 F.2d 923, 959 (D.C. Cir.) ("[C]ounsel argued ... [that] the expert testimony showed that at the critical moment Murdock did not have control of his conduct, and the reason for that lack of control was a deepseated emotional disorder that was rooted in his 'rotten social background." (quoting defense counsel)), cert. denied, 409 U.S. 1044 (1972); GRIER \& COBBS, supra note 4, at 209-10 (comparing the release of black rage to the sudden violent backswing of a bent sapling).

${ }^{87}$ MODEL PENAL CODE \$ 4.01(1) (1962) (alteration in original).

${ }^{88}$ See supra notes 76-78 and accompanying text (discussing the ambiguities of the M'Naghten test).

${ }^{89}$ See supra notes 83-84 and accompanying text (clarifying the meaning of "impulse"). 
substantial capacity" and thus departs from both earlier tests in requiring less than total incapacitation. ${ }^{90}$ As a result, the Model Penal Code test is broader-and some would say more realistic-than the earlier tests. ${ }^{91}$

Because the Model Penal Code test requires only a lack of "substantial capacity" to appreciate the criminality or wrongfulness of one's conduct or to control one's impulses, more instances of black rage will qualify as a sufficient mental disease or defect. ${ }^{92}$ As for the cognitive and volitional prongs, the Model Penal Code test essentially restates the satisfiable cognitive prong of the M'Naghten test and the satisfiable volitional prong of the irresistible impulse test. Accordingly, black rage defendants who meet those two insanity tests, or who fall just short, should be able to satisfy the slightly more lenient Model Penal Code test. ${ }^{93}$

\section{d. The Product Test}

A fourth insanity test focuses on whether an actor's criminal conduct is a product of a mental disease or defect. Pursuant to this "product test," an actor is excused as insane if he has a mental disease or defect that is a but-for cause of the criminal behavior charged. ${ }^{94}$ This broad and "dramatic departure" from

${ }^{90}$ See MODEL PENAL CODE $\$ 4.01$ explanatory note ("The standard does not require a total lack of capacity, only that capacity be insubstantial."); see also DRESSLER, supra note 16, at 302 (noting this important difference from earlier tests).

${ }^{91}$ About half of the states and all but one of the federal courts of appeals had adopted the popular Model Penal Code test by 1980. See Kadish \& ScHUlHOFER, supra note 33 , at 997 . With the rising tide of public resentment toward insanity verdicts in the early 1980 s, however, some jurisdictions rethought their insanity approaches and reverted to tougher M'Naghten-type tests. See DRESSLER, supra note 16, at 297 (noting a toughening of standards in Congress and in California); KADISH \& SCHULHOFER, supra note 33, at 997 (commenting upon this trend); see also supra note 79 (noting the connection between the public reaction to the John F. Hinckley acquittal and the toughening of insanity standards).

${ }_{92}$ See supra notes 80,86 and accompanying text (providing examples of black rage that approach or meet the $M$ 'Naghten and irresistible impulse definitions of insanity).

93 See MODEL PENAL CODE \$ 4.01(1).

F The product test first appeared in nineteenth-century New Hampshire. See State v. Jones, 50 N.H. 369, 398 (1871) (affirming a jury instruction that included the product test); State v. Pike, 49 N.H. 399, $407-08$ (1870) (same). It later surfaced in Durham v. United States, 214 F.2d 862, 874-75 (D.C. Cir. 1954) (utilizing the product test and citing Pike and Jones), overruled by United States v. Brawner, 471 F.2d 969 (D.C.Cir. 1972). As a result, the test is sometimes referred to as the New Hampshire test or the Durham test. The product test reigned supreme in the District of Columbia Circuit until 1972 when it was expressly overruled by United States v. Brawner, 471 F.2d 969, 973, 981-83 (D.C. Cir. 1972) (adopting the Model Penal Code 
traditional notions of criminal responsibility excuses actors who have control over and appreciate the wrongfulness of their actions but act anyway as a result of a mental condition. ${ }^{95}$ In addition to criticism on this ground, the product test faces criticism in that it relies too heavily on the existence of a mental disease or defect and, thus, gives too much power to expert psychiatric witnesses. ${ }^{96}$

The product test is more forgiving than the M'Naghten, the irresistible impulse, and the Model Penal Code tests, both with respect to the mental disease or defect requirement and with respect to the cognitive and volitional prongs. Instead of requiring a "disease of the mind" that only some psychoses and extreme mental defects can satisfy, ${ }^{97}$ or a lack of substantial capacity to understand or control, ${ }^{98}$ the product test includes "any abnormal condition of the mind which substantially affects mental or emotional processes and substantially impairs behavior controls." As a result of this lenient definition, more defendants could successfully assert a black rage defense under this part of the product test than under other insanity formulations. ${ }^{100}$ If these defendants could additionally show that black rage was a but-for cause of their criminal conduct, they would also satisfy the second part of the test and qualify as legally insane.

insanity test in place of the product test).

${ }^{95}$ See DRESSLER, supra note 16, at 304 (noting that, were it not rejected, the product test "could have served as the intellectual foundation" to expand criminal law excuses to include conduct caused by any condition beyond an actor's control). But see Moore, supra note 16, at 1129-31 (countenancing this proposal by distinguishing between compulsion, which merits exculpation, and mere causation, which does not).

${ }^{96}$ See DRESSLER, supra note 16, at 303 (stating that the legal profession criticized the product test for leaving the definition of mental disease or defect in the hands of psychiatrists).

${ }^{37}$ See supra note 70 and accompanying text (discussing the limited range of conditions that qualify as diseases of the mind for legal insanity).

${ }^{98}$ See supra note 93 and accompanying text (discussing the Model Penal Code test).

${ }^{99}$ McDonald v. United States, 312 F.2d 847, 851 (D.C. Cir. 1962).

${ }^{100}$ See, e.g., United States v. Alexander, 471 F.2d 923, 958-59 (D.C. Cir.) (noting that abnormal mental conditions excluded from other insanity tests may qualify under the applicable product test's more lenient definition), cert. denied, 409 U.S. 1044 (1972). 


\section{e. The Federal Test}

From the United States Congress comes a fifth and final insanity test, aptly called the "federal test." Under this test, an actor is legally insane if, at the time of the criminal conduct, he suffered from a "severe mental disease or defect" and as a result was unable to appreciate (1) the nature and quality of the conduct or (2) the wrongfulness of the conduct. ${ }^{101} \mathrm{~A}$ partial throwback to M'Naghten, the federal test replaces the Model Penal Code's more lenient "lack of substantial capacity" with the less forgiving "severe mental disease or defect" and removes completely the Model Penal Code's volitional prong. ${ }^{102}$ As a result, incapacitation must be cognitive and total, as in M'Naghten, in order to exculpate the accused. ${ }^{103}$

Unlike the M'Naghten test and like the Model Penal Code test, however, the federal test requires appreciation rather than knowledge of the nature and quality or wrongfulness of the criminal conduct. ${ }^{104}$ Thus, in this limited sense, the federal test is slightly broader than M'Naghten. Because the federal test "is essentially a restatement of the M'Naghten rule," the two will produce largely similar results. ${ }^{105}$ Thus, defendants acting in altered states of consciousness or under delusional beliefs that pass the M'Naghten right-wrong prong will similarly pass the federal test. ${ }^{106}$

${ }^{101}$ See 18 U.S.C. § 17(a) (1988); see also United States v. Salava, 978 F.2d 320, 322 (7th Cir. 1992) (construing the federal test).

${ }^{102}$ See, e.g., United States v. Fishman, 743 F. Supp. 713, 720 (N.D. Cal. 1990) (“[B]y purposeful exclusion, Congress rejected the various formulations of defects of volition which had been stated in other definitions of legal insanity. "); see also supra note 90 and accompanying text (discussing the lower "lacks substantial capacity" threshold).

${ }^{103}$ See, e.g., United States v. Reed, 997 F.2d 332, 334 (7th Cir. 1993) (affirming the conviction under the federal test of a defendant who had some ability to appreciate the wrongfulness of his actions); cf. supra note 90 and accompanying text (quoting the Model Penal Code's drafters who stated that their insanity test requires only "substantial" impairment, not "complete" impairment, of capacity).

${ }^{104}$ See supra note 75 and accompanying text (discussing the $M$ 'Naghten test's strict knowledge requirement; supra text accompanying note 88 (discussing the Model Penal Code test's more relaxed appreciation requirement).

${ }^{105}$ LAFAVE \& SCOTT, supra note 70, at 312 n.6. However, for the few courts that strictly interpret the $M$ 'Naghten "knowledge" wording, the change to "appreciate" will produce differences and will include more defendants within the ambit of legal insanity. See supra note 77 (discussing differing interpretations of knowledge in the M'Naghten test).

${ }^{106}$ See supra notes 80-81 and accompanying text (speculating as to the outcome of the black rage insanity defense under the M'Naghten test). 


\section{Similarity to Other Varieties of Insanity}

Because black rage is a new variation of the old insanity theme, little directly applicable precedent exists upon which one can conclusively rely to apply the various insanity tests with any degree of certainty. However, substantial bodies of insanity defense law that address paranoid schizophrenia, delusional disorder of the persecutory type, and post-traumatic stress disorder-three mental conditions similar to black rage-serve as useful, indirectly applicable guides. ${ }^{107}$ Analogizing from these established insanity defenses, this Section makes clear that black rage is sufficiently similar to other accepted varieties of insanity and suggests that black rage is itself a legitimate insanity defense. Accordingly, this Section describes paranoid schizophrenia, delusional disorder of the persecutory type, and post-traumatic stress disorder, discusses their success under the several insanity tests, and compares them to the black rage phenomenon.

\section{a. Paranoid Schizophrenia}

Paranoid schizophrenia may provide the basis for a successful insanity defense. According to the Diagnostic and Statistical Manual of Mental Disorders, paranoid schizophrenia features a "[p]reoccupation with one or more delusions or frequent auditory hallucinations." 108 Delusions are "typically persecutory or grandiose" and, when combined with anger (which is commonly present), "may predispose the individual to violence." ${ }^{\text {Hog }}$ Hallucinations

${ }^{107}$ Notably absent from these comparisons is the battered person's syndrome (a combination of the battered woman's syndrome and the abused child syndrome). If these syndromes were understood as criminal law excuses, on the theory that a woman or child is battered to the point where he or she misperceives threats and violently overreacts, the omission would be a serious oversight indeed. However, these syndromes operate in the criminal law as justifications that draw upon the self-defense defense, stretching the imminent danger requirement and subjectivizing the reasonable belief requirement. See Holly Maguigan, Battered Women and Self-Defense: Myths and Misconceptions in Current Reform Proposals, 140 U. PA. L. REV. 379, 397 (1991) (noting data showing that most battered women kill during confrontational situations); see also supra note 16 and accompanying text (classifying the battered person's syndrome as a justification and describing its operation). But see State v. Hoyt, 128 N.W.2d 645, 648 (Wis. 1964) (dealing with the battered woman's syndrome in conjunction with arguments and insults as heat-of-passion manslaughter). Therefore, the absence of these syndromes in the following discussion is intentional and acceptable.

${ }^{108}$ DSM-IV, supra note 65, at 287.

${ }^{109} \mathrm{Id}$. In addition to anger, "anxiety, . . . aloofness, and argumentativeness" are 
may occur via any sense but are most often auditory, causing the individual to enter into a dissociative state. ${ }^{110}$

The paranoid schizophrenic's delusions initially may seem intelligent or rational: "[I]ndeed, if one assumes the truth of the delusory belief, the paranoid's desperate measures are intelligible; some would even say rational. But eventually we come to see that what governs is the deluded person's deep, persistent, ultimately quite unfounded ... feelings of fear and enmity." ${ }^{111}$ When faced with independent, contradictory, relevant evidence, the paranoid schizophrenic will persist in his delusions-a key factor distinguishing delusory beliefs from merely false beliefs and paranoid schizophrenic actors from merely mistaken actors. ${ }^{112}$

The American Psychiatric Association classifies paranoid schizophrenia as a "psychotic disorder"113 that satisfies even the most stringent of the insanity test's "mental disease or defect" requirements. ${ }^{114}$ Further, a paranoid schizophrenic's persistent delusions or hallucinations likely will constitute sufficient interference with cognition, volition, or both. ${ }^{115}$ Thus, unable to appreciate the nature and quality of criminal actions or to resist acting on criminal impulses, paranoid schizophrenics will often qualify as legally insane actors under the different insanity tests. ${ }^{116}$

also commonly present in paranoid schizophrenics. Id.

${ }^{110}$ See id. at 275.

"11 Herbert Fingarette \& ANN F. HASSe, Mental. Disabilities AND Criminal RESPONSIBILITY 222 (1979) (footnote, internal quotation marks, and emphasis omitted).

${ }^{112}$ See id. (discussing the "immunity of the [paranoid's] beliefs and attitudes" from contradictory evidence).

${ }^{113}$ DSM-IV, supra note 65, at 274. Note, however, that although mere inclusion in the Manual may qualify a mental condition as a medical mental disorder, it does not necessarily qualify it as the "mental disease or defect" necessary for legal insanity. See Ira K. Packer, Post-Traumatic Stress Disorder and the Insanity Defense: A Critical Analysis, 11 J. PsYChIATRY \& L. 125, 126 (1983).

${ }^{114}$ See GolDSTEIN, supra note 67, at 60-61 (noting the quite widespread feeling among psychiatrists that all psychotics should be regarded as "insane"); Moore, supra note 16, at 1139 (noting that testifying psychiatrists generally include the extreme psychoses within the ambit of mental disease or defect).

${ }^{115}$ See, e.g., Colorado v. Connelly, 479 U.S. 157, 160-61 (1986) (describing hallucinations of "voices" that interfered with a schizophrenic defendant's volition and compelled him to confess); State v. Cameron, 674 P.2d 650,651-53 (Wash. 1983) (describing hallucinations of deific decrees and attacking spirits that interfered with a schizophrenic defendant's cognition).

${ }^{116}$ See, e.g., Cameron, 674 P.2d at 654, 656 (reversing defendant's conviction in light of excluded expert testimony on his mental condition and remanding to the trial court for further proceedings). 
Black rage, although not listed in the Diagnostic and Statistical Manual of Mental Disorders, shares several common characteristics with listed paranoid schizophrenia. Taken to an extreme, a "healthy' cultural paranoia" in which "every white man is a potential enemy unless proved otherwise and every social system is set against him unless he personally finds out differently ${ }^{\text {n117 }}$ is not unlike a paranoid schizophrenic's persecutory or grandiose delusions involving "deep, persistent, ultimately quite unfounded ... feelings of fear and enmity. ${ }^{118}$ Along these lines, two cases, both in the United States Court of Appeals for the District of Columbia, have acknowledged psychiatric testimony likening black rage to schizophrenia. ${ }^{119}$ Thus, when acting out of an exaggerated cultural paranoia, which presumably then becomes an unhealthy cultural paranoia, the black rage actor is not much different from the paranoid schizophrenic actor who generally qualifies as legally insane.

\section{b. Delusional Disorder, Persecutory Type}

Delusional disorder of the persecutory type may also provide the basis for a successful insanity defense. According to the Diagnostic and Statistical Manual of Mental Disorders, this form of psychosis features delusory beliefs that one "is being conspired

${ }^{117}$ GRIER \& COBBS, supra note 4, at 161, 178; see also Adcock, supra note 22, at 7 ("It is fundamentally a mental illness defense . . . . The insanity was generated by years of exposure to white racism." (quoting Ronald Kuby, one of Ferguson's former defense attorneys)).

${ }^{118}$ FINGARETTE \& HASSE, supra note 111 , at 222 . Recall that these persecutory delusions, when combined with anger, may drive a paranoid schizophrenic to violence. See supra note 109 and accompanying text (discussing the paranoid schizophrenic's tendency towards violence).

${ }^{119}$ See United States v. Robertson, 507 F.2d 1148, 1150, 1154-55 (D.C. Cir. 1974) (remanding for an insanity hearing in light of two psychiatric expert opinions that defendant suffered from schizophrenic "delusions of persecution and influence' . . contributing to impulsive and destructive behavior" (quoting one expert)); United States v. Alexander, 471 F.2d 923, 953 (D.C. Cir.) (accepting, if supported, psychiatric testimony diagnosing defendant as "alienated and sullen, with 'paranoid and sociopathic trends almost ingrained and severe enough to be [deemed] ... a character disorder'"), cert. denied, 409 U.S. 1044 (1972).

As evidenced by the notes in his pockets on the day of the Long Island Railroad shooting, Colin Ferguson suffered from similar persecutory delusions, believing that his university, the Equal Employment Opportunity Commission, the state workers' compensation board, the New York City transit police, the New York City police, former Governor Mario Cuomo, the state lieutenant governor, the rest of the New York state government, his landlord, and several black civil rights leaders were all out to get him. See Papers and Letter of Suspect, supra note 3, at B8. 
against, cheated, spied on, followed, poisoned or drugged, maliciously maligned, harassed, or obstructed in the pursuit of longterm goals." ${ }^{120}$ Overwhelmed with these feelings of injustice, those afflicted tend to interpret common or random events such as "small slights" as if they have special significance consistent with the disorder's persecutory theme. ${ }^{121}$ After a point, persons with delusional disorder of the persecutory type may engender feelings of resentment and anger and may engage in litigious behavior or "resort to violence against those they believe are hurting them." ${ }^{\text {"122 }}$

The American Psychiatric Association classifies delusional disorder of the persecutory type a "psychotic disorder"123 which satisfies even the strictest variation of the "mental disease or defect" requirement. ${ }^{124}$ When acting out of delusory beliefs, for example, beliefs that one is the target of a government conspiracy, an afflicted person may not be able to rationally evaluate and appreciate the criminal nature of his actions. ${ }^{125}$ Under these circumstances persons suffering from delusional disorder of the persecutory type may qualify as insane under the various insanity tests. ${ }^{126}$

Like delusional disorder of the persecutory type, black rage involves feelings of being cheated, spied on, followed, maligned, harassed, and obstructed in the pursuit of goals. In the case of black rage, however, these feelings are often rooted in reality. ${ }^{127}$ Further, the "small slights" and common or random events that the delusional disorder sufferer incorporates into his scheme of deluded beliefs are not unlike the constant flow of subtle stressors that fuel

${ }^{120}$ DSM-IV, supra note 65, at 298.

${ }^{121}$ See id.

${ }^{129} I d$.

123 Id. at 296.

${ }^{124}$ See GolDSTEIN, supra note 67, at 60-61 (noting that psychiatrists regard psychoses as satisfying the mental disease or defect requirement); Moore, supra note 16 , at 1139 (same).

125 See, e.g., Dixon v. State, No. CR93-968, 1994 WL 717042, at *4 (Ala. Crim. App. Dec. 29, 1994) (finding defendant suffering from delusional disorder of the persecutory type "unable to rationally evaluate and appreciate either her own actions or those of others"); Madison v. State, 620 So. 2d 62, 66 (Ala. Crim. App. 1992) (recanting expert testimony that defendant suffering from delusional disorder of the persecutory type could neither appreciate the criminality of his act nor conform his conduct to the requirements of law). insane).

${ }^{126}$ See, e.g., Dixon, 1994 WL 717042, at *9 (finding defendant-sufferer legally

${ }^{127}$ See, e.g., Cose, supra note 23, at F1 (describing how blacks are followed and harassed rather than helped while shopping); Pope, supra note 26, at 56 (describing how blacks are cheated through discrimination in the workplace). 
the black rage sufferer's intense distrust in a racist society. ${ }^{128}$ In addition, both the delusional disorder sufferer and the black rage sufferer share another unfortunate trait: the two may respond to real or perceived wrongs with a violent rage towards those who symbolize their torment. ${ }^{129}$ In light of these many similarities, the criminal law should not treat black rage differently than it treats delusional disorder of the persecutory type: both diseases should merit inclusion in the family of recognized insanity defenses.

\section{c. Post-Traumatic Stress Disorder}

Post-traumatic stress disorder may also provide the basis for a successful insanity defense. Post-traumatic stress disorder, also listed in the Diagnostic and Statistical Manual of Mental Disorders, features "persistent reexperiencing" of an extremely traumatic event involving death, injury, or a threat to one's physical integrity that the suffering individual experienced, witnessed, or learned about. ${ }^{130}$ Often, the extreme traumatic event or "stressor" consists of "military combat, violent personal assault ...., being kidnapped, being taken hostage, terrorist attack, torture, incarceration as a prisoner of war or in a concentration camp, natural or manmade disasters, severe automobile accidents, or being diagnosed

${ }^{128}$ Compare DSM-IV, supra note 65, at 298 (describing how delusional disorder sufferers incorporate small slights and everyday events into their schemes of deluded beliefs) with Alexander, supra note 4, at B5 (terming subtle stressors "micro-insults") and Cose, supra note 23, at F1 (relating the racial stress that middle-class blacks experience).

${ }^{129}$ According to his former defense attorney, Colin Ferguson was diagnosed as suffering from delusional disorder of the persecutory type. See Kuby Telephone Interview, supra note 5; see also Peter Noel, Rage of an Invisible Man: The Trials of Colin Ferguson, VILLAGE VOICE, Feb. 21, 1995, at 21, 25 ("[O]n the day the crime was committed, Colin Ferguson suffered from a 'delusional disorder of the persecutory type' and 'as a result of this disorder he lacked substantial capacity to understand what he was doing was wrong." (quoting examining psychiatrist Dr. Richard G. Dudley)). Dr. Dudley elaborated:

As is characteristic of this disorder, Colin Ferguson's behavior has ranged from the exaggeration of small slights, to litigious behaviors, to verbalized anger and resentment, to violence.... . In addition, his delusional beliefs have been so strong that he has consistently and repeatedly acted on these delusional beliefs, despite the fact that his actions might harm himself or others.

Id.

${ }^{130}$ DSM-IV, supra note 65 , at 424 . If the extreme traumatic event was learned about, as opposed to experienced or witnessed, the event must have involved the actual or threatened death, injury, or physical integrity of a family member or other close associate. See id. 
with a life-threatening illness." 131 Symptoms include guilt about surviving traumatic events that others did not; avoidance of situations or activities that resemble the causal traumatic event; "impaired affect modulation; self-destructive and impulsive behavior; dissociative symptoms; ... feelings of ineffectiveness, shame, despair, or hopelessness; feeling permanently damaged; . . . impaired relationships with others; [and] a change from the individual's previous personality characteristics." 132

Of those who do develop the disorder, ${ }^{133}$ only a small fraction suffer from the more acute symptoms of impulsive behavior and dissociation that may cause criminal conduct. ${ }^{134}$ When such disorder-prompted criminal conduct does occur, however, the actor may satisfy the irresistible impulse, the Model Penal Code, or the product insanity tests by demonstrating an inability to conform hisperhaps unconscious, perhaps impulsive-conduct to the requirements of law. ${ }^{135}$ The stricter M'Naghten and federal insanity tests, requiring that the actor neither understand nor appreciate the

${ }^{191}$ Id. Because post-traumatic stress disorder frequently affects combat veterans, it is also known as "shellshock," "battle fatigue," and "Vietnam Stress Syndrome." Daniel E. Speir, Application and Use of Post-Traumatic Stress Disorder as a Defense to Criminal Conduct, ARMY LAW., June 1989, at 17, 17.

132 DSM-IV, supra note 65, at 425; see also Speir, supra note 131, at 18 (discussing the manifestations of post-traumatic stress disorder). Extreme post-traumatic stress disorder may cause "flashback" dissociative states in which the sufferer unconsciously reenacts his traumatic episode. Frequently, for example, Vietnam veterans in such a state will act believing that they are back in Vietnam shooting at the enemy, when in reality they are shooting at innocent bystanders or police officers. See id.; see also Landy F. Sparr et al., Military Combat, Posttraumatic Stress Disorder, and Criminal Behavior in Vietnam Veterans, BULL. AM. ACAD. PsYCHIATRY \& L., Mar. 1987, at 141, 151 (discussing a defendant's "altered state of consciousness" resulting from posttraumatic stress disorder); of. supra note 109 and accompanying text (discussing dissociative states in paranoid schizophrenics).

133 Most people who experience an extremely traumatic event do not develop posttraumatic stress disorder. See Speir, supra note 131, at 17.

${ }^{134}$ See Packer, supra note 113, at 133 ("In rare instances some [post-traumatic stress disorder sufferers] may experience brief psychotic or dissociative states, during which they appear to be reliving or reenacting traumatic episodes."); Speir, supra note 131, at 18 ("Fortunately, most manifestations of [post-traumatic stress disorder] do not result in criminal conduct.").

${ }^{135}$ See Speir, supra note 131, at 18 (noting that the post-traumatic stress disorder defense is most successful in jurisdictions that have adopted the Model Penal Code); Davidson, supra note 58, at 422-27 (arguing that post-traumatic stress disorder has passed the irresistible impulse and the Model Penal Code tests in some cases); State v. Heads, No. 106-126 (La. Dist. Ct. Oct. 10, 1981) (finding the defendant, an exmarine who suffered from combat flashbacks, insane under the irresistible impulse test); see also supra part II.A.1.b-d (discussing the requirements of the irresistible impulse, the Model Penal Code, and the product insanity tests). 
wrongfulness of his conduct, are not so easily satisfied. ${ }^{136}$ To satisfy the M'Naghten right-wrong prong the defendant suffering from post-traumatic stress disorder must show that he acted in a true dissociative state-for example believing that he was acting in justifiable self-defense against a physical assault-or that he was back in combat conditions where otherwise criminal conduct is often "right" or "justifiable." 137

Post-traumatic stress disorder is particularly vulnerable to falsification or exaggeration. Although many people experience traumatic events, post-traumatic stress disorder affects few people and even fewer people severely. ${ }^{138}$ The temptation to fabricate post-traumatic stress disorder is especially great considering the "ease with which a savvy defendant can fake" the disorder's well-researched symptoms. ${ }^{139}$ Unless such a duplicitous defendant frustrates his own plan through indiscretion, ${ }^{140}$ the burden rests with experienced psychiatrists and juries to distinguish the legitimate post-traumatic stress claims from the phony ones. ${ }^{141}$

${ }^{136}$ The defendant in these jurisdictions must also prove that he did not understand the nature and quality of the act. See Speir, supra note 131, at 18; see also Briggs v. State, 715 S.W.2d 223, 226 (Ark. Ct. App. 1986) (convicting a post-traumatic stress disorder defendant whose alleged insanity fell short of the M'Naghten test); Packer, supra note 113, at 130-33 (describing a case study of a post-traumatic stress disorder victim who was found to be legally sane due to his goal-oriented, self-serving behavior during his offense).

${ }^{157}$ See State v. Cocuzza, No. 1484-79 (N.J. Super. Ct. May 27, 1981) (acquitting under the $M$ 'Naghten test a defendant suffering from post-traumatic stress disorder); Speir, supra note 131, at 18 (noting that in some instances the defense can meet the burden of proof under the $M^{\prime}$ 'Naghten test and the federal test, although it is difficult); Davidson, supra note 58, at 422-25, 427-34 (arguing that in some instances posttraumatic stress disorder has passed the M'Naghten test and would pass the then-new federal test); see also supra part II.A.I.a, e (discussing the M'Naghten and the federal insanity tests).

${ }^{138}$ See supra notes 133-34 and accompanying text (noting the infrequency of posttraumatic stress disorder).

${ }^{139}$ Speir, supra note 131, at 19 (discussing People v. Lockett, 468 N.Y.S.2d 802, 806 (Sup. Ct. 1983), in which, after the state had accepted a plea bargain, it was discovered that the defendant claiming post-traumatic stress disorder had served his entire military stint as a clerk in combat-free Texas); see also Sparr et al., supra note 132 , at 153 (noting that post-traumatic stress disorder is a difficult diagnosis to confirm).

${ }^{140}$ See Speir, supra note 131, at 19 (discussing State v. Simonson, 669 P.2d 1092, 1096 (N.M. 1983), in which a defendant frustrated his own plan to fake post-traumatic stress disorder).

${ }^{141}$ See Packer, supra note 113, at 133-34 (placing the burden on the court and on mental health professionals to document better the rates of successful treatment of post-traumatic stress disorder sufferers to provide the courts with an improved basis for determining whether a defendant's claim is true or false); Sparr et al., supra note 
Vietnam veterans have been particularly successful at using posttraumatic stress disorder insanity defenses. ${ }^{142}$ Realistically, one must attribute at least some of this success to a deft manipulation of "the emotional baggage left over from the Vietnam War." 143 To obtain an acquittal, one attorney recommended "play[ing] off the collective guilt of the country over Vietnam ... . In rural, red-neck areas, people are patriotic. And in the urban areas, they're guiltridden over the war." 144

Like post-traumatic stress disorder, black rage arises from mental stresses and can cause depression, grief, impulsive behavior, resentment, and dissociative symptoms. ${ }^{145}$ However, whereas post-traumatic stress disorder results from one extremely traumatic stressor, black rage results from a steady flow of extremely subtle stressors that in and of themselves may seem minor but when taken as a whole may profoundly affect the psyche. ${ }^{146}$ In this sense, black rage may be seen as a kind of gradual post-traumatic stress without a well-defined burst of trauma.

As with post-traumatic stress disorder, most people that experience constant racial stress do not develop black rageparticularly not to the level at which they cannot control themselves or perceive rationally. ${ }^{147}$ However, this raises the same criticism that plagues post-traumatic stress disorder: black rage's vulnerability to falsification or exaggeration. ${ }^{148}$ Indeed, although black rage

132, at 154-56 (discussing post-traumatic stress disorder assessment).

142 See supra notes 135, 137 and infra note 144 (citing successful post-traumatic stress disorder insanity defenses). But see supra note 136 (citing Briggs v. State, 715 S.W.2d 223 (Ark. Ct. App. 1986), in which the defendant mounted an unsuccessful post-traumatic stress disorder defense).

${ }^{145}$ Speir, supra note 131, at 20.

144 Id. (quoting the attorney in United States v. Tindall, No. 79-376 (D. Mass. Sept. 19,1980 ) (involving the acquittal of a Vietnam veteran on criminal charges)).

${ }^{145}$ Compare DSM-IV, supra note 65, at $424-29$ (discussing the symptoms of posttraumatic stress disorder) and Speir, supra note 131, at 18 (same) with GRIER \& COBBS, supra note 4, at 205-06, 209-10 (discussing like symptoms of black rage) and Adcock, supra note 22, at 7 (same).

${ }^{146}$ Compare DSM-IV, supra note 65, at 424 (discussing the traumatic stressors that may cause post-traumatic stress disorder) with Alexander, supra note 4, at B5 (calling these subtle stressors "micro insults") and Cose, supra note 23, at F1 (discussing subtle stressors in the lives of middle-class blacks).

${ }^{147}$ Compare Speir, supra note 131, at 17 ("Even though a person may experience an extremely traumatic event ... there is no reason to assume that he or she will develop a [post-traumatic stress disorder]; in fact, most people do not.") with Alexander, supra note 4, at B5 ("Most blacks take a healthy point of view on dealing with discrimination and racism.").

${ }^{148}$ See supra notes $133-34$ and accompanying text (discussing the infrequency of 
does not yet command any accepted symptomology, a savvy defendant could surely take advantage of the existing black rage literature together with the insanity defense case law in order to try to fake the defense. ${ }^{149}$ Nevertheless, protecting against this danger does not require abolishing the entire concept of a black rage insanity defense; it merely requires safeguards similar to those used when a defendant claims post-traumatic stress disorder: experienced psychiatrists and, as always, wary juries concerned with making the correct findings of fact. ${ }^{150}$

In addition, black rage and post-traumatic stress disorder affect juries in a similar way. Whereas Vietnam veterans can elicit the country's emotional baggage of the Vietnam War, blacks in America can remind juries of hundreds of years of slavery, discrimination, and racism. ${ }^{151}$ This black rage strategy plays to the white juror's sense of guilt and to the black juror's sense of solidarity. ${ }^{152}$

Perhaps even more than paranoid schizophrenia and delusional disorder of the persecutory type, post-traumatic stress disorder provides an apt analogy for black rage. In their origins, in their effect on juries, and even in their drawbacks, black rage and posttraumatic stress disorder share much in common. The criminal law should respond accordingly, accommodating black rage as it has post-traumatic stress disorder.

\section{B. Diminished Capacity}

The diminished capacity defense contains two mutually exclusive but nevertheless intertwined strains: a mens rea strain and a partial responsibility strain. The mens rea strain is technically not a defense at all; it operates to defeat the prosecution's prima facie case by showing that the actor, as a result of an abnormal mental condition short of insanity, did not have the mental capacity to

post-traumatic stress disorder).

${ }^{149} C f$. supra notes $139-40$ and accompanying text (discussing the temptation to fake a post-traumatic stress disorder defense). Indeed, many people have accused Colin Ferguson and his attorneys of faking the black rage defense. See, e.g., DERSHOWITZ, supra note 10, at 89-91, 323 (criticizing Ferguson's former attorney William Kunstler for "creat[ing]" the defense).

${ }^{150}$ See supra notes 140-41 and accompanying text (discussing the role of the court and medical practitioners in preventing fraudulent defenses).

${ }^{151}$ See, e.g., GRIER \& COBBS, supra note 4, at 181-99 (describing years of discrimination and oppression); supra note 32 and accompanying text (same).

${ }^{152}$ See DERSHOWITZ, supra note 10, at 90 (calling black rage strategy "play[ing] the race card"); cf. Speir, supra note 131, at 20 (surmising that Vietnam Stress Syndrome appeals to guilt and patriotism). 
formulate the required mens rea component of the crime charged. ${ }^{153}$ In contrast, the partial responsibility component is a true but partial defense, excusing an actor of some responsibility for his criminal conduct on account of an abnormal mental condition short of insanity. ${ }^{154}$ Whereas the mens rea variant enjoys considerable acceptance, ${ }^{155}$ its partial responsibility cousin is far less popular and is only followed in some states-and there only as a mitigating defense reducing murder to manslaughter. ${ }^{156}$

\section{Common Law Jurisdictions}

Common law jurisdictions that accept the partial responsibility strain of diminished capacity ${ }^{157}$ generally limit its application to circumstances in which a provoked actor kills his provoker in the sudden heat of passion. ${ }^{158}$ In these jurisdictions, the actor must

$15 s$ See DRESSLER, supra note 16 , at 320 (discussing the underlying nature of the diminished capacity defense); Peter Arenella, The Diminished Capacity and Diminished Responsibility Defenses: Two Children of a Doomed Marriage, 77 CoLUM. L. REv. 827, $828,830 \mathrm{n} .17$ (1970) (distinguishing the strains but ultimately arguing that the two are in function "virtually indistinguishable"); Stephen J. Morse, Undiminished Confusion in Diminished Capacity, 75 J. CRIM. L. \& CRIMINOLOGY 1, 5-9 (1984) (reaffirming Arenella's distinction and arguing that courts should adopt only the mens rea strain).

154 See DRESSLER, supra note 16, at 322-25 (discussing arguments against full recognition of the defense); Arenella, supra note 153, at 829 (noting that the partial responsibility strain "opens the courtroom doors to most psychological testimony concerning the accused's mental disabilities"); Morse, supra note 153, at 20 (arguing against the adoption of the partial responsibility strain because actors with mental problems short of insanity should be able to avoid offending the law).

155 See DRESSLER, supra note 16, at 320 ("A few states, including those that follow the Model Penal Code, recognize the defense as appropriate regarding all crimes. Most states, however, limit the defense to some or all specific-intent offenses. Other states do not recognize the defense at all."); Arenella, supra note 153, at 829 \& $\mathrm{n} .11$ (noting the mens rea strain's acceptance and citing cases in support of that notion).

156 See DRESSLER, supra note 16, at 325 (noting that by 1978 only 15 states had adopted the partial responsibility version of the diminished capacity defense as suggested by the Model Penal Code); Morse, supra note 153, at 21 (noting that the Model Penal Code version has been adopted in a substantial number of jurisdictions). Where the partial responsibility strain mitigates a murder charge, the accused will be guilty of the lesser offense of voluntary manslaughter. See, e.g., MODEL PENAL CODE $\$ 210.3(1)(b)$ (1962) ("Criminal homicide constitutes manslaughter when ... a homicide which would otherwise be murder is committed under the influence of extreme mental or emotional disturbance for which there is reasonable explanation or excuse.").

${ }^{157}$ See, e.g., ALA. CODE $\S 13 A-6-3-(a)(2)$ (1977) (setting forth a heat of passion provision); N.J. STAT. ANN. § 2C:11-4b(2) (West 1981) (same).

${ }^{158}$ See, e.g., State v. Douglas, 407 P.2d 117, 119 (Ariz. Ct. App. 1965) (finding that a quarrel provoked by the deceased could have created the requisite heat of passion); People v. Wickersham, 650 P.2d 311, 327 (Cal. 1982) (noting that the assailant must 
kill before he has an opportunity to reflect on the situation and cool down. ${ }^{159}$ Additionally, the provoking event must be such that an ordinary person of average mind and disposition would be similarly provoked and inclined to act as the provoked actor did. ${ }^{160}$ Whereas in some jurisdictions only physical violence and witnessing adultery meet this latter requirement, ${ }^{161}$ in other less restrictive jurisdictions, any conduct or words that might cause a reasonable person to lose self-control may warrant a jury instruction. ${ }^{162}$

While the anger inherent in black rage would qualify as passion under the common law formulation of heat of passion mitigation, ${ }^{163}$ black rage would likely fall short of other common law requirements. Because black rage results from a simmering resentment built up over a long period of time, ${ }^{164}$ there may not

act "under the smart of that sudden quarrel or heat of passion"); People v. Borchers, 325 P.2d 97, 102 (Cal. 1958) (defining passion as any "violent, intense, high-wrought, or enthusiastic emotion").

${ }^{139}$ See, e.g., State v. Yanz, 50 A. 37, 38 (Conn. 1901) (requiring that the homicidal act occur "in the first transport of passion"); State v. Gounagias, 153 P. 9, 9 (Wash. 1915) (refusing a jury instruction on diminished capacity where the court found sufficient cooling-off time had elapsed). But see People v. Berry, 556 P.2d 777, 778 (Cal. 1976) (permitting the jury to determine reasonable cooling-off time in an extreme case).

${ }^{160}$ See, e.g., Addington v. United States, 165 U.S. 184, 186 (1897) (holding adequate a provocation that "would render any ordinary prudent person for the time being incapable of that cool reflection that otherwise makes it murder"); People v. Webb, 300 P.2d 130, 139 (Cal. Dist. Ct. App. 1956) (holding adequate a provocation that would be such as "tend to arouse the passion of an ordinarily reasonable man").

${ }^{161}$ See Stewart v. State, 78 Ala. 436 (1885) (holding that a blow in the face intentionally inflicted on the defendant by the deceased might constitute adequate provocation); Jones v. People, 47 P. 275, 277 (Colo. 1896) (holding adequate the witnessing of adultery); Yanz, $50 \mathrm{~A}$. at 38 (same); $c f$. People v. Valentine, 169 P.2d 1, 15 (Cal. 1946) (holding inadequate words, no matter how insulting).

${ }^{162}$ See Maher v. People, 10 Mich. 212, 222 (1862) (" [I]f the alleged provocation be such as to admit of any reasonable doubt, whether it might not have had such tendency, it is much safer ... and more in accordance with principle, to let the evidence go to the jury under the proper instructions."). Most common law jurisdictions prefer the Maher position to the restrictive position. See KADISH \& SCHULHOFER, supra note 33, at 442 ("The restrictive view has now given way, in most jurisdictions, to the position adopted by the majority in Maher. . .".). But see, e.g., Aguilar v. State, 242 S.E.2d 620, 624 ( $\mathrm{Ga}$. 1978) (adhering to the restrictive position and holding that the trial court did not invade the province of the jury when it charged that provocation by words is always inadequate to reduce murder to manslaughter); State v. Guebara, 696 P.2d 381, 385 (Kan. 1985) (same); Commonwealth v. McGuirk, 380 N.E.2d 662, 667 (Mass. 1978) (same); State v. Madden, 294 A.2d 609, 620 (N.J. 1972) (same).

${ }^{163}$ See supra note 158 and accompanying text (describing passion as including violent, intense emotions).

${ }^{164}$ See supra notes 21-32 and accompanying text (setting forth the psychiatric and 
be any specific provocation that would qualify as legally adequate. ${ }^{165}$ Furthermore, since a person venting his black rage strikes not at the causes of the rage but rather at the symbols of the rage, he usually kills innocent bystanders rather than provokers. The defendant thereby disqualifies himself from the common law provocation partial defense. ${ }^{166}$

\section{Model Penal Code Jurisdictions}

\section{Model Penal Code jurisdictions ${ }^{167}$ take a broader approach to}

sociological basis for black rage).

${ }^{165}$ See supra notes 160-62 and accompanying text (discussing the common law adequacy requirement). Even if there were a specific provocation-such as wordsinvolved in black rage situations, it would still be inadequate in the common law jurisdictions requiring provocation more severe than offensive words or situations. See supra notes 158-62 and accompanying text (discussing the more and less restrictive adequacy requirements).

${ }^{166}$ See supra note 158 and accompanying text (discussing the common law requirement that an actor kill his provoker).

${ }^{167}$ Hawaii and Montana have adopted the Model Penal Code extreme mental or emotional disturbance provision verbatim. See HAW. REV. STAT. § 707-702 (1985 \& Supp. 1992) (reducing murder to manslaughter where defendant was under the influence of extreme mental or emotional disturbance for which there is a reasonable explanation"); MONT. CODE ANN. § 45-5-103 (1993) (defining the affirmative defense of "extreme mental or emotional stress" as requiring a "reasonable explanation or excuse"). New Hampshire and Utah have adopted the provision without its subjective reasonableness standard. See N.H. REv. STAT. ANN. \$ 630:2 (1986 \& Supp. 1993) (stating that a person is guilty of manslaughter if he was "[u]nder the influence of extreme mental or emotional disturbance"); UTAH CODE ANN. § 76-5-205 (1992 \& Supp. 1994) ("The reasonableness of an explanation. . . shall be determined from the viewpoint of a reasonable person ...."). Arkansas, Connecticut, Delaware, Kentucky, New York, North Dakota, and Oregon have adopted an extreme emotional disturbance provision, omitting the word "mental." See ARK. CODE ANN. § 5-10-104 (Michie 1987) (allowing a defense of "extreme emotional disturbance for which there is a reasonable excuse," as viewed from the circumstances as the defendant believed them to be); CONN. GEN. STAT. ANN. \$§ 53a-54a(a) (West 1994) ("[I]t shall be an affirmative defense that the defendant [acted] ... under the influence of extreme emotional disturbance for which there was a reasonable explanation ... to be determined from the viewpoint of a person in the defendant's situation under the circumstances as the defendant believed them to be . ..."); DEL. CODE ANN. tit. 11, \$ 641 (1987 \& Supp. 1994) (requiring that the defendant prove his extreme emotional distress); KY. REV. STAT. ANN. § 507.020 (Michie/Bobbs-Merrill 1990 \& Supp. 1994) (stating that extreme emotional disturbance must be established by a reasonable explanation determined from the viewpoint of a person in the defendant's situation); N.Y. PENAL LAW § 125.20 (McKinney 1987 \& Supp. 1995) (stating that committing a crime "under the influence of extreme emotional disturbance constitutes a mitigating circumstance reducing murder to manslaughter"); N.D. CENT. CODE § 12.116-01(2) (1985 \& Supp. 1993) (mitigating a homicide caused "under the influence of extreme emotional disturbance for which there is reasonable excuse" from a class AA felony to a class A felony); OR. REV. STAT. $\$ 163.115$ (1)(a) (1990 \& Supp. 1994) 
the partial responsibility strain of diminished capacity, merely requiring that an actor kill under the influence of an extreme mental or emotional disturbance." 168 This disturbance must be such that "there is [a] reasonable explanation or excuse ... [to] be determined from the viewpoint of a person in the actor's situation under the circumstances as he believes them to be. ${ }^{n 169}$ To fall within the scope of this definition, a defendant must typically show that he:

(a) has no mental disease or defect that rises to the level [of legal insanity]; and

(b) is exposed to an extremely unusual and overwhelming stress; and

(c) has an extreme emotional reaction to it, as a result of which there is a loss of self-control and reason is overborne by intense feelings, such as passion, anger, distress, grief, excessive agitation, or other similar emotions. ${ }^{170}$

The extreme mental or emotional disturbance formulation incorporates two distinct prongs: a common law provocation prong (emotional disturbance), and a partial insanity prong (mental disturbance). ${ }^{171}$ The former prong operates much like common law provocation but without its stringent per se requirements. Thus, under the Model Penal Code, there need not be a welldefined triggering event provoking the actor; ${ }^{172}$ nor need the

(providing an affirmative defense if the defendant "was under the influence of an extreme emotional disturbance").

${ }^{168}$ MODEL PENAL CODE § 210.3(1)(b) (1962). As to the independent significance of the word "extreme," see Richard Singer, The Resurgence of Mens Rea: I-Provocation, Emotional Disturbance, and the Model Penal Code, 27 B.C. L. Rev. 243, 303 (1986) ('[T] $\mathrm{T}$ he phrase 'emotional and mental disturbance' is to be read as a single term of art, rather than parsed.").

${ }^{169}$ MODEL PENAL CODE $\$ 210.3(1)(b)$. The drafters of the Model Penal Code explain in their commentaries, "In the end, the question is whether the actor's loss of self-control can be understood in terms that arouse sympathy in the ordinary citizen. Section 210.3 . . . leaves the ultimate judgment to the ordinary citizen in the function of a juror assigned to resolve the specific case." MODEL PENAL CODE § 210.3 cmt.; of. supra notes 160-62 and accompanying text (discussing the reasonableness inquiry of the common law approach to the provocation mitigation).

${ }_{170}$ People v. Shelton, 385 N.Y.S.2d 708, 717-18 (Sup. Ct. 1976) (setting forth the leading definition of extreme emotional disturbance); see also State v. Elliott, $411 \mathrm{~A} .2 \mathrm{~d}$ 3, 8 (Conn. 1979) (following the Shelton definition); State v. Trieb, 315 N.W.2d 649, 659 (N.D. 1982) (same); State v. Carson, 640 P.2d 586, 590 (Or. 1982) (same).

${ }^{171}$ But see supra note 167 (noting that seven Model Penal Code jurisdictions have explicitly omitted the word "mental," and thus the mental prong, from the provision).

${ }^{172}$ See, e.g., Elliot, $411 \mathrm{~A} .2 \mathrm{~d}$ at 7 ("[T] bance] does not require a provoking or triggering event ...."); People v. Casassa, 404 N.E.2d 1310 (N.Y. 1980) ("[I]t may be that a significant mental trauma has 
actor kill the individual that causes his mental or emotional disturbance. ${ }^{173}$ Accordingly, the pitfalls encountered under the common law formulation would not hinder a black rage extreme emotional disturbance defense, rendering a defendant's crime eligible for mitigation. ${ }^{174}$

The latter, partial insanity prong offers the black rage defendant an additional avenue through which to argue for diminished capacity mitigation. ${ }^{175}$ Because extreme mental disturbance constitutes a lower legal hurdle than does legal insanity, instances of black rage will more readily qualify under the partial insanity prong of the Model Penal Code. Consequently, a black rage defendant who, through expert testimony, can convince a jury that there is a "reasonable explanation or excuse" for his mental condition $^{176}$ will merit partial exoneration, thereby reducing his conviction from murder to voluntary manslaughter.

\section{ANALYSIS OF THE EXISTING LAW}

Although the preceding analysis demonstrates that black rage neatly fits into both the insanity defense ${ }^{177}$ and the Model Penal Code formulation of the diminished capacity partial defense, ${ }^{178}$ these results prove troubling for the utilitarian and retributivist penal schemes underlying the criminal law. ${ }^{179}$ In addressing these concerns, this Part examines the results of the preceding analysis through utilitarian and retributivist lenses, ultimately concluding

affected a defendant's mind for a substantial period of time, simmering in the unknowing subconscious and then inexplicably coming to the fore." (quoting People v. Patterson, 383 N.Y.S.2d 573, 582 (1976))).

${ }^{173}$ See, e.g., MODEL PENAL CODE $\$ 210.3 \mathrm{cmt}$; State v. Zdanis, 438 A.2d 696, 700 (Conn. 1980) (hinting that on different facts the court would uphold a manslaughter verdict where the defendant killed a non-provoker).

${ }^{174}$ See supra notes 164-66 and accompanying text (discussing the problems inherent in a common law black rage provocation defense).

${ }^{175}$ Of course, this avenue is only open in Model Penal Code jurisdictions retaining the original wording of the provision. See supra note 167 (noting that only some of the Model Penal Code jurisdictions have retained the wording of the model provision).

${ }^{176}$ See supra note 169 and accompanying text (discussing the reasonable explanation or excuse requirement of the Model Penal Code formulation of diminished capacity).

177 See supra part II.A (discussing the black rage insanity defense).

178 See supra part II.B (discussing the black rage diminished capacity defense).

179 See supra part I.B.1 (discussing the utilitarian and retributivist approaches to punishment theory). 
that black rage diminished capacity rather than black rage insanity is the better role for the black rage defense in the criminal law.

\section{A. Insanity and Culpable Coping Mechanisms}

While those afflicted with black rage may qualify as legally insane in that they act without the deterrability and sense of moral blameworthiness necessary to inflict punishment under the utilitarian and retributivist penal schemes, black rage actors should not be permitted to externalize the entirety of moral and legal responsibility onto society. Although society, through its pervasive and persistent racism, has laid the foundation for the destructive coping mechanisms that lead to black rage, the potential black rage sufferer chooses to resort to those mechanisms rather than to pursue more rational, constructive ones. ${ }^{180}$

In that the choice to deal destructively with racial stress is one born of free will, the black rage actor is both deterrable and morally blameworthy. Accordingly, under the utilitarian and retributivist penal theories, the criminal law should hold him at least partially responsible for his resulting criminal actions. In similar contexts involving involuntary movements, courts have expressed a willing-

${ }^{180}$ See Stephen J. Morse, Culpability and Control, 142 U. PA. L. REV. 1587, 1615 (1994) (" $[\mathrm{A}] \mathrm{n}$ excuse will not obtain if the agent was responsible either for placing herself in the situation or for failing to employ possible, resistant strategies. An agent who causes or fails to prevent the circumstances of her own excuse should not profit thereby."); id. (noting that "avoidance and resistance strategies are often genuinely possible" in a mental abnormality context). See generally Moore, supra note 16, at 1130 (positing that all human actions are caused but arguing that only those causes which are compelled warrant a criminal law excuse: "compulsion requires an agent who reasons about what to do but whose opportunity or capacity to follow the normal dictates of that reason is interfered with either by external factors (threats, natural necessity) or internal factors (extreme emotion or cravings)"); Stephen J. Morse, The Twilight of Welfare Criminology: A Reply to Judge Bazelon, 49 S. CAL. L. REV. 1247, 1252 (1976) ("[A person's] environment is not all-determinative: it interacts with intrapersonal factors.").

Indeed, most blacks faced with persistent racial stress deal with it constructively rather than destructively. See, e.g., COMER \& POUSSAINT, supra note 25, at 64 (suggesting that black parents help their children deal with racism constructively); WRIGHT, supra note 28, at xii-xiii (noting that some blacks deal with racial stress constructively by turning to religion, education, or music); Alexander, supra note 4, at B5 ("Most blacks take a healthy point of view on dealing with discrimination and racism ...."); see also U.S. CoNST. amend. XIV, § 1 (providing a legal means of dealing with denials of "equal protection of the laws"); 42 U.S.C. \$ 1983 (1988) (creating a civil cause of action for the deprivation of constitutional rights); Civil Rights Act of 1964, 42 U.S.C. $\$ 2000$ e-2(a)(1) (1988) (providing a legal means of dealing with discrimination regarding "compensation, terms, conditions, or privileges of employment" on the basis of "race, color, religion, sex, or national origin"). 
ness to look back in time to find voluntary, deterrable, and morally culpable acts. ${ }^{181}$ Thus, holding a black rage actor criminally responsible despite his mental illness produces a result consistent with utilitarianism, retributivism, and criminal law precedent. ${ }^{182}$

\section{B. Diminished Capacity and Shared Blame}

The rationale behind the diminished capacity defense suggests that it is the most appropriate role for the black rage defense in the criminal law. As a mitigating partial excuse, diminished capacity apportions blame between the two causal and blameworthy partiesthe black rage actor and the society that had a hand in creating him. This blame-sharing solution accomplishes the retributive and utilitarian goal of punishing deterrable and deserving actors, ${ }^{183}$ and also focuses societal attention on the larger social causes of black rage: pervasive and persistent discrimination and oppression. ${ }^{184}$

${ }^{181}$ See, e.g., State v. Gooze, 81 A.2d 811,816 (N.J. Super. Ct. App. Div. 1951) (placing the burden on a known sufferer of Ménière's Syndrome to foresee the dangers inherent in operating a motor vehicle and to refrain from such behavior accordingly); People v. Decina, 138 N.E.2d 799, 803-04 (N.Y. 1956) (placing the burden on a known epileptic to foresee the dangers inherent in operating a motor vehicle and to refrain from such behavior accordingly); Norval Morris, Somnambulistic Homicide: Ghosts, Spiders, and North Koreans, 5 RES JudicATAE 29, 29-30 (1951) (discussing a case in which the court could have placed a similar burden on a known somnambulist who killed her daughter while both were asleep); $c f$. Martin v. State, 17 So. 2d 427, 427 (Ala. Ct. App. 1944) (acquitting the accused of manifesting a drunken condition in public because he was "involuntarily and forcibly carried to that place by the arresting officer"). See generally Paul H. Robinson, Causing the Conditions of One's Own Defense: A Study in the Limils of Theory in Criminal Law Doctrine, 71 VA. L. REV. 1 (1985).

${ }^{182}$ Furthermore, to the extent that other victimization defenses attempt to eschew the entirety of criminal responsibility onto society, they too do not merit an insanity defense. See supra note 18 and accompanying text (citing examples of victimization defenses such as child abuse syndrome, rotten social background, and urban survival syndrome).

${ }^{18 s}$ See supra part III.A (explaining the extent to which black rage actors are deterrable and morally culpable).

${ }^{184}$ See Delgado, supra note 24, at 21 ("As a result of learning about the wretched conditions in which some of its members live, society would presumably decide to do something about them."); John L. Hill, Note, Freedom, Determinism, and the Externalization of Responsibility in the Law: A Philosophical Analysis, 76 GEO. L.J. 2045, 2071 (1988) (noting that, following externalization principles, "[n]o longer is an individual party picked out as the 'cause' of a particular act[,] [r]ather, larger groups, institutions, and society at large become the responsible causes"). But see DERSHOWITZ, supra note 10, at 40 (noting that legally excusing an actor driven to criminal conduct by a societal problem is 'little more than a rhetorical, 'feel-good,' cheap, short-term nonsolution to [the] complex and pressing societal problem that deserves real solutions, high priority, and significant allocation of resources"). 
Diminished capacity not only reaches a practical compromise that is tolerable from a theoretical perspective of balancing individual and societal culpability but also recognizes a principled difference in the respective effects of external and internal factors. External forces ranging from racist environments to witnessing adultery can trigger profound human responses. By reducing the degree of moral responsibility to below that of a calculating killer while refusing to exculpate entirely, diminished capacity recognizes human weakness, holding individuals accountable only for controlling their responses to external forces. In this respect, diminished capacity consigns external forces and internal responsibility each to the respective role that befits them.

\section{CONCLUSION}

In light of the dearth of black rage cases, the viability of a black rage insanity defense or a black rage diminished capacity defense is far from certain. Applying the black rage psychiatric and sociological studies to the legal definitions of insanity reveals that black rage may, at least in some instances, pass even the strictest of insanity tests. The paranoid schizophrenia, the delusional disorder of the persecutory type, and the post-traumatic stress disorder analogies further point to this conclusion, implying that black rage is a form of legal insanity that the criminal law should recognize. Similarly extrapolating from the existing diminished capacity case law, one can foresee that black rage diminished capacity would encounter problems under the common law heat of passion formulation but would, as a matter of law, reach the jury under the analogous Model Penal Code provision.

However, insofar as black rage insanity is the product of an actor's choice to pursue destructive rather than constructive coping mechanisms as a means of dealing with racial stress, the contraction of black rage represents a deterrable, blameworthy choice that is subject to criminal law punishment. Black rage diminished capacity more accurately balances individual and societal responsibility for black rage, recognizing that environments replete with racial stress will interfere with, yet not quite eclipse, one's free will. Thus, punishing only to the extent that a black rage actor remains legally and morally responsible, diminished capacity better than insanity expresses societal empathy, if not remorse, while satisfying the traditional goals of the criminal law. 